Document de Recherche du Laboratoire d'Économie d'Orléans DR LEO 2017-04

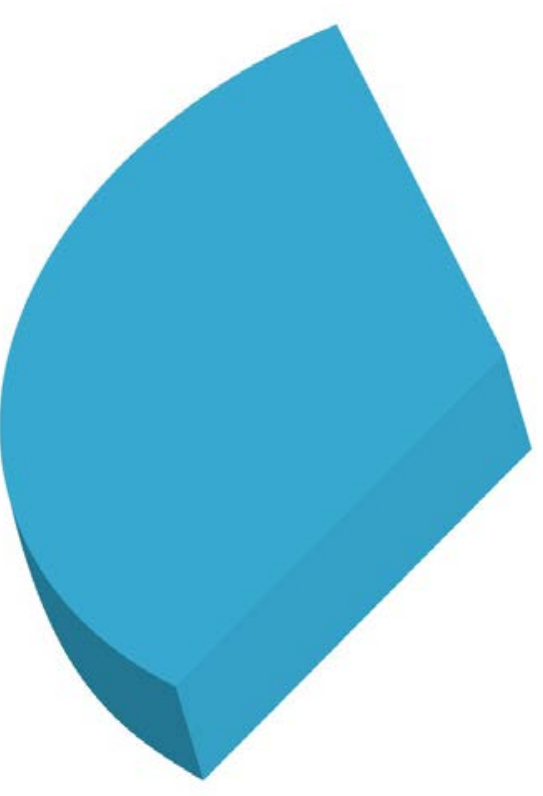

Investigating First-Stage Exchange Rate Pass-Through: Sectoral and Macro Evidence From Euro Area Countries

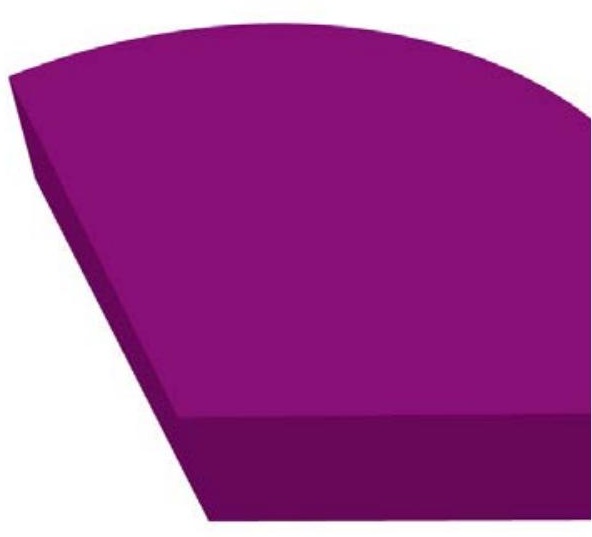

Nidhaleddine BEN CHEIKH

Christophe RAULT

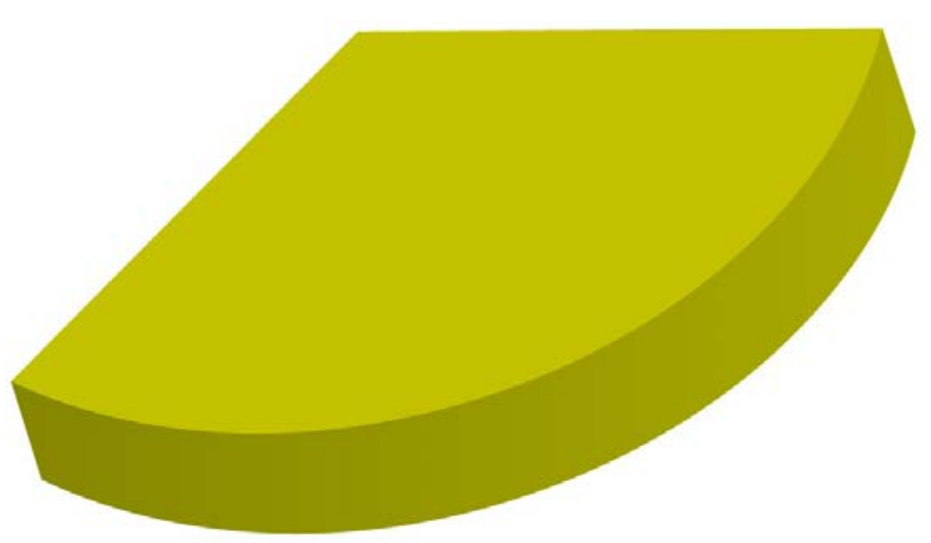




\title{
Investigating First-Stage Exchange Rate Pass-Through: Sectoral and Macro Evidence from Euro Area Countries
}

\author{
Nidhaleddine Ben Cheikh \\ ESSCA School of Management, Angers, France \\ E-mail: nbcheikh@gmail.com \\ Christophe Rault \\ Univ. Orléans, CNRS, LEO, UMR 7322, F45067, Orléans, France \\ E-mail: chrault@ hotmail.com, website: http://chrault3.free.fr/ (Corresponding Author)
}

\begin{abstract}
In this paper, we evaluate the first-stage pass-through, namely the responsiveness of import prices to the exchange rate changes, for a sample of euro area (EA) countries. Our study aims to shed further light on the role of microeconomic factors vs. macroeconomic factors in influencing the extent of the exchange rate pass-through (ERPT). As a first step, we conduct a sectoral analysis using disaggregated import prices data. We find a much higher degree of pass-through for more homogeneous goods and commodities, such as oil and raw materials, than for highly differentiated manufactured products, such as machinery and transport equipment. Our results confirm that cross-country differences in pass-through rates may be due to divergences in the product composition of imports. The higher share of imports from sectors with lower degrees of pass-through, the lower ERPT for an economy will be. In a next step, we investigate for the impact of some macroeconomics factors or common events experienced by EA members on the extent of pass-through. Using the System Generalized Method of Moments within a dynamic panel-data model, our estimates indicate that decline of import-price sensitivity to the exchange rate is not significant since the introduction of the single currency. Our findings suggest instead that the weakness of the euro during the first three years of the monetary union significantly raised the extent of the ERPT. This outcome could explain why the sensitivity of import prices has not fallen since 1999 . We also point out a significant role played by the inflation in the Eurozone, as the responsiveness of import prices to exchange rate fluctuations tends to decline in a low and more stable inflation environment. Overall, our findings support the view that the extent of pass-through is comprised of both macro- and microeconomic aspects that policymakers should take into account.
\end{abstract}

J.E.L classification: E31, F31, F40

Keywords: exchange rate pass-through, import prices, dynamic panel data 


\section{INTRODUCTION}

Understanding the determinants of the exchange rate pass-through (ERPT) continues to be essential to central bankers whose goal is price stabilization. This issue is of particular importance for a monetary union such as the euro area (EA). Forgoing their local currencies to join a monetary union has posed a significant challenge to European countries, since a country adopting the euro cedes its monetary policy to the European Central Bank (ECB) and no longer has the option of using its monetary policy to respond to local conditions. Nevertheless, as the main objective of the monetary policy of the ECB is to achieve mediumterm price stability for the Eurozone aggregate, this may be seen as a sign of increasing credibility of the monetary regime for the countries belonging to the euro area. This is especially true for countries with historically higher levels of inflation, such as Greece, Italy, Portugal, and Spain.

As argued in the ERPT literature, more stable monetary policy conditions within a credible and anti-inflationary regime tend to reduce the degree to which currency changes are transmitted to domestic prices (e.g., Taylor, 2000). ${ }^{1}$ Hence, it could be assumed that the start of Stage III of the European Monetary Union (EMU) in January 1999 would affect the behavior of the pass-through across EA countries. In addition to this change in a macroeconomic environment, there are other reasons that may explain why the rate of passthrough might have changed as a result of the introduction of the euro. The proportion of trade exposed to exchange rate movements diminished after the adoption of the single currency, leading to change in the relative degree of openness in the monetary union members (e.g., Campa and Goldberg, 2005; De Bandt et al., 2008).

Furthermore, since the start of the monetary union, the EA countries have been subject to substantial fluctuations in the euro exchange rate. During the first 3 years of its existence, the euro experienced a large depreciation of roughly $45 \%$ against the U.S. dollar and about $25 \%$ on a trade-weighted basis. This extensive depreciation was followed by roughly the same magnitude of appreciation between 2002 and 2004 (see Figure 1). These wide swings have raised concerns of higher inflation variability. In particular, the euro weakness may likely raise the cost of imports and producer prices, which can feed into higher consumer prices. Also, it has been pointed out that the pass-through was higher until the end of the Exchange Rate Mechanism (ERM) crisis of the European Monetary System in 1992-1993, an episode during which many European currencies experienced substantial depreciations. Following this

\footnotetext{
${ }^{1}$ In a more recent literature, the degree of pass-through in emerging market economies is found to be low and close to that for advanced economies. A more stable inflation environment has played a substantial role in the diminishing sensitivity of import prices to exchange rate changes (see e.g. Devereux and Yetman, 2014; BrunAguerre et al., 2012).
} 
period of instability, there was a decline in the ERPT for the majority of EA members. ${ }^{2}$ In order to estimate an aggregate ERPT for the EA as a whole and to investigate the impact of such common factors or events, we propose to use a dynamic panel data framework that enables us to estimate an aggregate ERPT for the EA as a whole and to investigate the impact of common factors or events.

Another important issue in the ERPT literature is related to the prevalence of microeconomic or macro-economic factors in explaining the extent of pass-through. More specifically, there is a substantial debate regarding the sources of the low and declining degree of ERPT that has been observed in most of the industrialized countries. This phenomenon has both macro- and microeconomic aspects, but the literature is not conclusive about whether the macro- or micro-factors are most important.

A prominent study frequently cited in this regard is that of Campa and Goldberg (2005) who differentiated microeconomic from macroeconomic explanations for the recent decline in the responsiveness of import prices to exchange rate movements. The authors concluded that changes in the composition of imports towards goods whose prices are less sensitive to exchange rate movements, such as differentiated goods in the manufacturing sector, were the primary driver behind recent ERPT changes among several OECD countries. Known as the Campa-Goldberg compositional-trade hypothesis, this phenomenon is believed to explain the lion's share of the decline in pass-through over the past decades (see e.g., Goldberg and Tille, 2008). As "macro" analysis and aggregate estimates could potentially mask the wide dispersion of the ERPT across the EA countries, we propose first to examine the importance of microeconomic factors, mainly the product composition of trade, using disaggregated import price data for each EA country. The methodology for estimation draws heavily on Campa et al. (2005) and Campa and Gonzàlez (2006), whose results are updated here.

The purpose of this paper is to provide further insights on the pass-through features for Eurozone countries. We begin firstly by implementing a sectoral analysis, using disaggregated data from different industries in a sample of EA countries, in order to examine the importance of the composition of imports in explaining the cross-country differences in the extent of pass-through. In a next step, we estimate a dynamic panel data model to provide an aggregate ERPT into import prices for the EA as a whole. The advantage of this framework is that it allows us to test for the influence of common events experienced by the EA countries, such as the ERM crisis or the formation of the euro, upon the responsiveness of import prices to currency changes.

\footnotetext{
${ }^{2}$ See Ben Cheikh and Rault (2016) for a recent discussion of this issue.
} 
To preview our results, within the disaggregated import price data analysis, we found a much higher degree of pass-through for more homogeneous goods and commodities, such as oil and raw materials, than for highly differentiated manufactured products, such as machinery and transport equipment. Our results confirm that divergences in the product composition of imports can account for a significant amount of the cross-country differences in pass-through rates. The higher share of imports from sectors with lower degrees of passthrough, such as the manufacturing sector, the lower the country-ERPT will be (and vice versa). As regards our aggregate dynamic panel data framework, we reveal that decline of import-price sensitivity to the exchange rate since the inception of the euro is not significant. However, we point out the significant role played by inflation in influencing the ERPT. According to our estimates, the responsiveness of import prices to exchange rate fluctuations tends to decline in a low and more stable inflation environment. Moreover, our findings suggest that the weakness of the euro during the first 3 years of the monetary union significantly raised the extent of pass-through. We believe that this outcome could explain why the sensitivity of import prices has not fallen since 1999.

The remainder of the paper is organized as follows: In Section 2, we expose the model specification strategy, introduce the data, and discuss a few methodological issues. In Section 3 , we provide a sectoral analysis of the degree of pass-through. In Section 4, within a dynamic panel-data model, we test the impact of some macro factors/events on ERPT. Section 5 summarizes our major findings and concludes.

\section{MODEL SPECIFICATION STRATEGY, DATA, AND METHODOLOGY}

\section{(a) Specification of the empirical model}

The standard specification used in the pass-through literature is based on the pricing behavior of exporting firms. Under imperfect competition, we consider a foreign firm exporting its product to a given importing country while facing competition from the producers in the same market. The exporting firm solves the following profit maximization problem:

$\max _{P} \Pi=E^{-1} P^{m} Q\left(P^{m}, P^{d}, Y\right)-C\left(Q(),. W^{*}\right)$

where $E$ is the exchange rate measured in units of the importer's currency per unit of the exporter's currency, $P^{m}$ is the import price of the product in the importing country, and $Q($. is the demand for the product that depends not only on original price but also on the price of the domestic competing product, $P^{d}$, and the income level, $Y$. The production $\operatorname{cost} C($.$) is$ 
determined by the level of the demand for the product and the input price $W^{*}$ measured in the exporter's currency units.

The first-order condition for a profit maximizing firm leads to the following equation:

$P^{m}=E C_{q} \mu$

where $C_{q}$ is the marginal cost and $\mu$ is the markup of price over marginal cost. The markup is further defined as $=\eta /(\eta-1)$, where $\eta$ is the price elasticity of demand for the product that depends on variables specific to the importing country, mainly, demand conditions $Y$ and the price of the competing product $P^{d}$. When estimating the pass-through elasticity, it is important to isolate the exchange rate impact from other effects, i.e., the exporter's cost shifter, the importer's demand conditions, and the price of the domestic competitor. Therefore, in a static framework, we can capture the arguments of the import price Eqn.(2) through a log-linear regression specification similar to that tested throughout the ERPT literature as follows:

$p_{t}^{m}=\beta_{0}+\beta_{1} e_{t}+\beta_{2} w_{t}^{*}+\beta_{3} z_{t}+\varepsilon_{t}$

where $z_{t}$ is a vector including demand conditions and competitors' prices in the importing country, among other control variables. ${ }^{3}$

However, it is well-known that the responses of import prices to exchange rate changes may not be fully manifested instantaneously, especially when foreign firms take time to adjust their prices in the domestic currency. Therefore, as emphasized by some empirical studies, it is important to account for the potential inertial behavior of import prices by estimating a dynamic model (see e.g., Bussière, 2013; Olivei, 2002; Yang, 2007). This is typically accomplished by including lagged import prices as an explanatory variable, which allows for the possibility of delayed adjustment of domestic-currency import prices. ${ }^{4}$

Also, for our macro analysis, we need to adapt Eqn.(3) to be suitable for estimating an aggregate ERPT for the EA as a whole within a panel data framework. One of the main advantages of using panel data models is that they allow for the identification of countryspecific effects. The country-specific effects are designed to account for any unobservable or missing characteristics that vary across countries and that influence import prices. For instance, they could capture different foreign producers pricing strategies, i.e. producer

\footnotetext{
${ }^{3}$ Lowercase letters in Eqn.(2) denote logarithmic values of the variables.

${ }^{4}$ Other models (e.g., Marazzi et al., 2005) do not include the lagged dependent variable but include more lags of the explanatory variables instead.
} 
currency pricing ( $P C P$ strategy) or local currency pricing ( $L C P$ strategy), when exporting their goods to Eurozone countries. Also, if there are unobserved characteristics that are common to all countries but vary across time, then we can use time fixed effects. As matter of fact, our study intends to test for the influence of common factors or events experienced by the EA countries that may influence import-price changes, such as the ERM crisis or the creation of the euro. Furthermore, the use of time dummies would allow to capture the effects of global shocks, such as the recent financial turmoil or the European sovereign debt crisis. Thus, a country-specific effect, $\alpha_{i}$, and a time dummy, $\mu_{t}$, are introduced in our empirical specification.

To gauge the importance of the different factors discussed above, we modify the static pass-through Eqn. (3) to have all the elements of a dynamic panel data model as follows:

$p_{i, t}^{m}=\alpha_{i}+\mu_{t}+\beta_{1} e_{i, t}+\beta_{2} w_{i, t}^{*}+\beta_{3} g a p_{i, t}+\beta_{4} p_{i, t-1}^{m}+\varepsilon_{i, t}$

where $\alpha_{i}$ is a country-specific effect, $\mu_{t}$ is a time dummy, $p_{i, t}^{m}$ is the domestic currency import prices, $e_{i, t}$ is the nominal exchange rate, $w_{i, t}^{*}$ is a variable representing the exporters' costs, $g a p_{i, t}$ is the output gap to proxy for domestic demand changes that may alter foreign firms' markup, $p_{i, t-1}^{m}$ the lagged term to capture the inertia in the import prices dynamics, and $\varepsilon_{i, t}$ the disturbance term assumed to follow the standard assumptions. ${ }^{5}$ In Eqn.(4), it is possible to estimate the immediate effect of the exchange rate on import prices, i.e. the short-run ERPT given by the coefficient $\beta_{1}$. Moreover, due to the lagged adjustment of import-price inflation, the long-run ERPT can be computed as $\beta_{1} /\left(1-\beta_{4}\right)$.

It is important to note that some empirical studies propose to consider both at import and export prices which would enhance the understanding of the pass-through mechanism. There is a tight connection between export and import prices as export prices set by foreign producers are reflected in domestic import prices. Facing exchange rate changes, exporters can decide whether or not to adjust their markups. When the currency of the importing country is depreciating, a foreign firm might cut its price by reducing its markup in order to

\footnotetext{
5 As a proxy for foreign firms' markup, it is possible to use domestic producer prices as an indicator for the competitors' prices in the importing country (see e.g., Olivei, 2002; Bussière, 2013, among others). Also, as is well-known, changes in the exchange rate also influence import prices indirectly through their effects on commodity prices. Thus, it is possible to consider this channel by including oil prices as an additional explanatory variable in the pass-through equation. As explained by Ihrig et al. (2006), when it was not possible to find import prices of core goods that exclude all primary raw commodities, the inclusion of commodity prices indexes, such as oil prices, as independent variables should mitigate some of the noise generated by these volatile components. To check for robustness, we have estimated our pass-through equation with the use of different proxies which does not alter significantly the results of our benchmark specification. These results are not reported here to save space but are available upon request.
} 
stabilize its price in the destination market, then pass-through is less than complete. Exchange rate induced markup adjustment is usually referred in the ERPT literature as "pricing-tomarket" strategy. The greater the degree of pricing-to-market, the lower the extent of passthrough. Thus, dealing with the export side would indeed shed a complementary light on exporters' pricing strategy and, hence, the level of pass-through. Also, studying the elasticity of export prices to exchange rate changes would highlight the complementary role of exporting country's economic conditions in influencing the pass-through. For example, a decline in pass-through for a given country could be explained by a rise in inflation abroad, rather than a fall in domestic inflation. While our paper primarily aimed at measuring passthrough rates from import-price equation, simultaneously estimating export and import prices equations could be a possible extension for future research. ${ }^{6}$

\section{(b) Data description and their properties}

We consider quarterly data over the period 1990:1-2013:4 for 12 EA countries: Austria, Belgium, Finland, France, Germany, Greece, Ireland, Italy, Luxembourg, Netherlands, Portugal, and Spain. For each country, the data we use are taken from the OECD's Economic Outlook database, except for exchange rate series that are obtained from the International Financial Statistics (IFS) database of the International Monetary Fund (IMF). Concerning the dependent variable, i.e., the domestic import prices, we use import unit values indices of goods and services. ${ }^{7}$ This represents import prices of core goods by excluding primary raw commodities because of their marked volatility. As regards our sectoral analysis, disaggregated import price series are only available at monthly frequency over the period 1995:01-2013:12. Also, the sectoral ERPT is measured only for only eleven EA countries due to the lack of sufficient disaggregated data for Luxembourg. The disaggregated monthly import price data for our EA countries are monthly indexes of import unit values obtained from the Eurostat COMEXT database. For all countries, we employed the nominal effective trade-weighted series for the exchange rate, with an increase meaning a depreciation of the national currency and a decrease meaning an appreciation of the national currency. Concerning the marginal costs of foreign producers (that are difficult to measure since they are not directly observable), a proxy variable needs to be used. A conventional practice is to calculate a weighted average of trade partners' costs as in Campa and Goldberg (2005) and Bailliu and Fujii (2004). Following this, the foreign costs of each EA country's major trade partners is derived implicitly here from the nominal and real effective exchange rate series as

\footnotetext{
${ }^{6}$ It is noteworthy that studying the export side is more relevant for the issue of price competitiveness and its consequence on the external balance (see e.g. Bussière, 2013).

7 The import prices indices do not exclude primary raw commodities for comparison purpose with sectoral analysis in Section 3. Reestimating our benchmark equation using import prices of core goods (excluding primary raw commodities) does not alter our results.
} 
follows: $w_{t}^{*} \equiv q_{t}-e_{t}+u l c_{t}$, where $u l c_{t}$ is the domestic unit labor cost (ULC) and $q_{t}$ is the ULC-based real effective exchange rate. Given that the nominal and real effective exchange rate series are trade-weighted, this proxy provides a measure of trading partner costs, with each partner weighted by its importance in the importing country's trade. As regards foreign firms' markup, we use the output gap as the difference between actual and HP-filtered gross domestic product (GDP) to proxy for changes in domestic demand conditions. ${ }^{8}$

Before estimating the degree of ERPT for our 12 EA countries, we inspect the behavior of our key macro variables namely, the exchange rate changes $(\Delta e)$, import prices inflation $\left(\Delta p^{m}\right)$ and consumer prices inflation $(\Delta c p i)$. For these macroeconomic variables, the quarterly average for the mean and for the standard deviation over 1990- 2013 are summarized in Table 1. Average import-price inflation was the largest in Belgium followed by Greece and Italy, while in terms of volatility, i.e. standard deviation, Greece and Ireland have the highest values. As regards consumer prices, peripheral countries such as Spain, Greece, Ireland and Portugal has the less stable inflation rates both in value and volatility terms. However, the so-called "core" EA countries, such as Austria, Belgium, Germany and France exhibit low average inflation rates and, consequently, some more stable macroeconomic conditions than peripheral EA members.

Next, we can explore the link between our key macro variables. In Table 1, we provide an overview of the simple correlation between quarterly changes in price series and exchange rate over 1990-2013. Regarding import-price changes, the expected positive correlation with the currency movements is evident for all the EA countries, except for Austria. The tightest relationships are found in Spain, Ireland and Italy, while the level of the correlation coefficient is notably low in the case of France. For Belgium, although the high import-price inflation over the sample period, the relationship with exchange rate is weaker than expected. With regard to consumer-price inflation, the co-movement with the nominal exchange rate is much lower than recorded with import-price inflation. In the half of the EA countries, we have a wrong (negative) sign of correlation coefficients. However, on the other side, we found that exchange rate depreciation is positively associated with higher inflation rates of consumer prices, especially, for Greece, Italy and Portugal. This not surprising given the inflationary record of this group of country. Nevertheless, these results represent a statistical correlation without specific economic interpretation in terms of ERPT. Therefore, in Section 3 and Section 4, we provide an econometric analysis using more economically meaningful specifications to assess the relationship between exchange rates and prices.

\footnotetext{
${ }^{8}$ The HP-filter of the GDP series (as an estimate of potential) was constructed using a smoothing parameter of 14.400 .
} 
Table 1. Summary statistics of key variables over 1990-2013

\begin{tabular}{|c|c|c|c|c|c|c|c|c|}
\hline \multirow{2}{*}{ Country } & \multirow{2}{*}{$\begin{array}{c}\text { Correlation } \\
(\Delta m p, \Delta e)\end{array}$} & \multirow{2}{*}{$\begin{array}{c}\text { Correlation } \\
(\Delta c p i, \Delta e)\end{array}$} & \multicolumn{3}{|c|}{ Mean (\%) } & \multicolumn{3}{|c|}{ Standard Deviation (\%) } \\
\hline & & & $\Delta m p$ & $\Delta c p i$ & $\Delta e$ & $\Delta m p$ & $\Delta c p i$ & $\Delta e$ \\
\hline Austria & -0.07 & -0.20 & 0.19 & 0.54 & -0.33 & 0.63 & 0.57 & 0.88 \\
\hline Belgium & 0.27 & -0.06 & 1.79 & 0.52 & -0.32 & 1.57 & 0.47 & 1.27 \\
\hline Finland & 0.33 & 0.18 & 0.36 & 0.45 & 0.27 & 1.97 & 0.44 & 2.39 \\
\hline France & 0.13 & -0.06 & -0.01 & 0.44 & -0.09 & 1.34 & 0.37 & 1.20 \\
\hline Germany & 0.36 & -0.02 & -0.02 & 0.45 & -0.18 & 1.22 & 0.47 & 1.45 \\
\hline Greece & 0.41 & 0.59 & -0.82 & 1.61 & 0.40 & 5.73 & 1.94 & 1.68 \\
\hline Ireland & 0.62 & 0.04 & -0.38 & 0.62 & 0.06 & 3.89 & 0.79 & 2.19 \\
\hline Italy & 0.65 & 0.26 & 0.76 & 0.76 & 0.34 & 2.03 & 0.46 & 2.33 \\
\hline Luxembourg & 0.20 & -0.06 & 0.71 & 0.55 & -0.09 & 2.12 & 0.50 & 1.12 \\
\hline Netherlands & 0.26 & -0.09 & 0.10 & 0.55 & -0.06 & 1.28 & 0.43 & 1.41 \\
\hline Portugal & 0.28 & 0.22 & 0.33 & 0.98 & 0.05 & 1.49 & 0.96 & 1.23 \\
\hline Spain & 0.62 & 0.11 & 0.42 & 0.84 & 0.21 & 2.08 & 0.80 & 1.67 \\
\hline
\end{tabular}

Source: OECD, IMF \& personal calculation.

Another point that deserves more attention is related to the sizable swings of the euro since 1999 as shown in Figure 1. The single currency depreciated strongly against the U.S. dollar in 1998 through 2001, followed by an appreciation of roughly the same magnitude between 2002 and 2004. During the first two years of his existence, the euro depreciated by approximately $25 \%$ in a nominal trade-weighted basis, and since the second quarter of 2002, it started to appreciate regaining about $20 \%$ of its value by the end of 2004 . It is expected that such movements can put substantial pressures on domestic prices. The concern about the exchange rate affecting price stability during this episode has been clearly expressed in the ECB reactions. The contractionary monetary policy in 2000 was a response to the inflationary effects of the weakness of the euro, while the loosening in 2003 is due to the disinflationary effects of a strong euro. Otherwise, it should be noted that some industrialized countries have similarly experienced a considerable depreciation of the exchange rate without domestic prices being affected as much as expected. This was the case of Canada, Sweden, and the United Kingdom in the 1990s. Therefore, to ensure the potential strong relationship between exchange rate and import prices during the first years of the creation of the EA, a relevant econometric methodology must be employed before drawing any definite conclusions. 


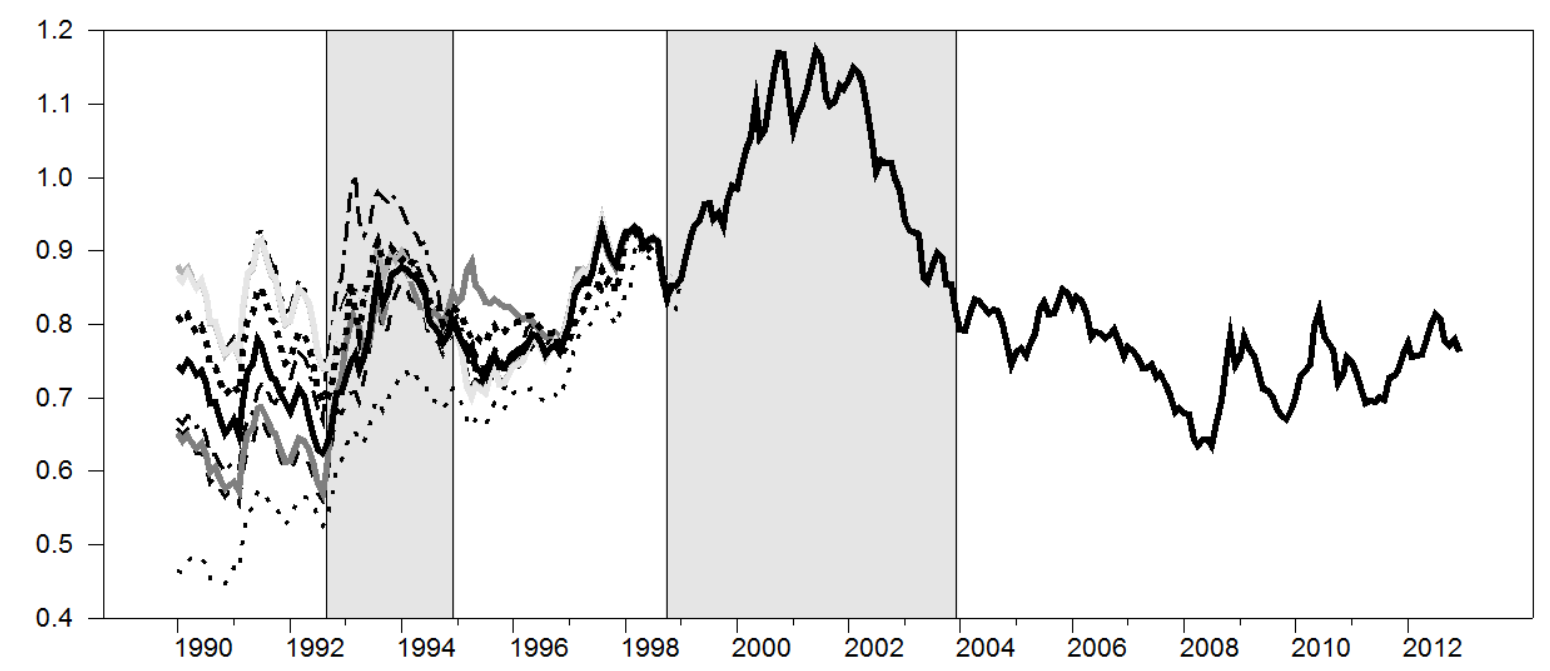

Figure 1. European currencies during the last two decades

Source: IMF's International Financial Statistics. Note: Plots correspond to bilateral US dollar against European currencies, where an increase means a depreciation of the European currency (USD vs. EUR).

(c) Methodological considerations

The presence of the lagged dependent variable $\Delta p_{i, t-1}^{m}$ in Eqn.(4) gives rise to autocorrelation, which prevents us from using standard econometric techniques such as OLS, Between, Within, or MCG. As shown by Nickell (1981), the Least Squares Dummy Variables (LSDV) estimator, for instance, has a non-vanishing bias for small $T$ and large $N$. It is well-known that the estimates of the coefficients of Eqn.(4) obtained with standard techniques can be biased for many reasons, including measurement error and omitted variable bias. To deal with some of these problems, it is possible to use fixed-effects instrumental variables (IV) estimation (such as two-stage least squares or 2SLS). However, as shown by Arellano and Bover (1995), in the first-stage statistics of the 2SLS regressions, many instruments are often weak, and with weak instruments, the fixed-effects IV estimators are likely to be biased in the way of the OLS estimators (see for instance Roodman, 2006). Therefore, a number of methods were proposed to estimate dynamic panel data models with a short time dimension, in which lagged values of the explanatory endogenous variables are used as instruments. Such methods control for endogeneity and measurement error not only of the lag of the domestic import prices, but also of other explanatory variables.

In our analysis, we employ the System Generalized Method of Moments estimator (SYS-GMM) developed by Arellano and Bover (1995), which combines a regression in differences with one in levels. Blundell and Bond (1998) present Monte Carlo evidence that including the level regression in the estimation reduces the potential bias infinite samples and 
the asymptotic inaccuracy associated with the difference estimator. ${ }^{9}$ The consistency of the GMM estimator depends on the validity of the instruments used in the model and the assumption that the error term does not exhibit serial correlation. To obtain valid instruments, we followed the recommendations of Roodman (2009) who addresses the problem of too many instruments. ${ }^{10}$ One of them is limiting the lag depth, another is "collapsing" the instrument set. The former implies a selection of lags to be included in the instrument set, making the instrument count linear in $T$. The latter embodies a different belief about the orthogonality condition: it no longer needs to be valid for any one time period but still for each lag, again making the instrument count linear in $T$. A combination of both techniques makes the instrument count invariant to $T$. In our case, we use the collapsed two (or three)period lags from all variables included in each estimation as the instruments sets, which provides the results "SYS-GMM1" and "SYS-GMM2" reported in Section 4.

Moreover, we implement two specification tests to address the consistency of the SYS-GMM estimator. The first one is a serial correlation test that tests the null hypothesis of no second-order serial correlation in the residuals in the first-differenced equation. The second one is a Sargan/Hansen test of overidentifying restrictions that examines the overall validity of the instruments by comparing the moment conditions with their sample analogue. A finite sample correction is made to the two-step covariance matrix using the Windmeijer's (2005) method.

Furthermore, we perform panel unit-root tests belonging to the second-generation (allowing for cross-country dependence) as in Pesaran (2007). The results, as reported in Table 8 in Appendix A, suggest that all series are non-stationary in levels but stationary when first differenced. ${ }^{11}$ The only exception is the output gap which is by construction a stationary variable. Finally, we implement a cointegrating analysis using error-correction-based panel cointegration tests developed by Westerlund (2007) that have good small-sample properties and high power relative to popular residual-based panel cointegration tests (Pedroni, 2004). The tests are designed to test the null hypothesis of no cointegration by testing whether the

\footnotetext{
${ }^{9}$ The basic idea of the first-differenced GMM estimator is to write the regression equation as a dynamic panel data model, take first-differences in order to remove unobserved time-invariant country-specific effects, and then instrument the right-hand-side variables in the first-differenced equations using levels of the series lagged two periods or more, under the assumption that the time-varying disturbances in the original levels equations are not serially correlated.

${ }^{10}$ The main small-sample problem caused by numerous instruments is that a large instrument collection overfits endogenous variables even as it weakens the Hansen test of the instruments' joint validity. Specifically, "if for instance $T=3$, the system GMM generates only two instruments per instrumenting variable. But as T rises, the instrument count can easily grow largely relative to the sample size, making some asymptotic results about the estimators and related specification tests misleading" (see Roodman, 2009, for further details on this issue).

${ }^{11}$ A common feature of the panel unit root tests by Pesaran (2007) is that they maintain the null hypothesis of a unit root in all panel members. Therefore, a failure to reject their null can be interpreted unambiguously as evidence for non-stationary holding in the entire panel.
} 
error correction term in a conditional error correction model is equal to zero. If the null hypothesis of no error correction is rejected, then the null hypothesis of no cointegration is also rejected. As shown in Table 9 in Appendix A, we are not able to reject the null, and consequently, since variables are integrated of order one (except output gap) but not cointegrated, our benchmark dynamic panel-data model has the following form:

$\Delta p_{i, t}^{m}=\alpha_{i}+\mu_{t}+\beta_{1} \Delta e_{i, t}+\beta_{2} \Delta w_{i, t}^{*}+\beta_{3} g a p_{i, t}+\beta_{4} \Delta p_{i, t-1}^{m}+\varepsilon_{i, t}$

where $\Delta$ denotes the difference operator.

\section{A SECTORAL ANALYSIS OF THE PASS-THROUGH}

As discussed before, an aggregate measure may hide a potential dispersion in the ERPT rates across the monetary union members. ${ }^{12}$ To assess this possible cross-country differences in our sample, we start by providing individual estimates of the degree of pass-through. Thus, Eqn.(5) is reestimated for each Eurozone country separately. ${ }^{13} \mathrm{We}$ focus on the short-run sectoral ERPT by calculating the coefficient $\beta_{1 i}$ for each EA country. ${ }^{14}$ Results of individual regressions for "country-ERPT" are reported in the last row of Table 3. We observe that import-price pass-through elasticities are positively significant in all EA countries and lie between $0.29 \%$ (for Austria) and $0.59 \%$ (for Italy). We point out that import-price passthrough elasticities are in some extent heterogeneous across our sample of EA countries. This pattern is line with the recent literature on ERPT in the currency union members (see e.g. Ben Cheikh and Rault, 2016).

In order to shed further light on the determinants of these pass-through coefficients. We now provide a micro-level analysis of the ERPT, prior to an aggregate macro analysis. In fact, there is a substantial debate concerning the prevalence of micro or macro factors in explaining the ERPT. A prominent study frequently cited in this regard is Campa and Goldberg's (2005); they differentiate micro-economic from macro-economic explanations for the recent decline in the responsiveness of import prices to exchange rate movements. The authors conclude that changes in the composition of imports towards goods whose prices are

\footnotetext{
${ }^{12}$ Auer and Mehrotra (2014) underlined the limitation of country-level data since it is difficult to control for all the relevant factors that could possibly affect price co-movement at an aggregate level.

${ }^{13}$ We have implemented the efficient unit-root test suggested by Elliott et al. (1996) to check the stationarity of the individual series our key variables. Results of unit-root tests applied to variables taken in first differences confirm the stationarity of all variables.

${ }^{14}$ It is possible to calculate long-run sectoral ERPT by calculating the coefficient $\beta_{1 i} /\left(1-\beta_{4 i}\right)$ for each country. As a matter of fact, there is less dispersion between countries in terms of ERPT in the long-run. Results are not reported here to save space but are available upon request.
} 
less sensitive to exchange rate movements, such as differentiated goods in the manufacturing sector, have been the primary driver behind recent ERPT changes among several OECD countries. Known as the "Campa-Goldberg compositional-trade hypothesis", this phenomenon is believed to explain the lion's share of the decline in pass-through over the past decades (see e.g., Goldberg and Tille, 2008).

Prior to our next macro-level analysis, we first check for the importance of microeconomic factors, mainly the product composition of trade, using disaggregated import price data for each EA country (except for Luxembourg, due to the lack of sufficient sectoral data). The methodology for estimation draws heavily on Campa et al. (2005) and Campa and Gonzàlez (2006), whose results are updated here.

Therefore, we run separate regressions within our previous dynamic ERPT Eqn.(5) for each "country $i$ - sector $j$ ” pair using disaggregated import price data:

$$
\Delta p_{i, j, t}^{m}=\alpha_{i j}+\beta_{1 i j} \Delta e_{i, t}+\beta_{2 i j} \Delta w_{i, t}^{*}+\beta_{3 i j} g a p_{i, t}+\beta_{4, i, j} \Delta p_{i, j, t-1}^{m}+\varepsilon_{i, j, t}
$$

The same industry classification for all the EA countries in the sample is used in order to maintain some comparability of the industry estimations across countries. Hence, the disaggregated import price data for each country corresponds to the 1-digit level of disaggregation in the Standard International Trade Classification (SITC) for nine different industry categories as reported in Table $2 .{ }^{15}$ The product disaggregation is as follows: 0. Food and live animals, 1. Beverages and tobacco, 2. Crude materials, inedible, 3. Mineral fuels, 4. Oils, fats and waxes, 5. Chemical products, 6. Basic manufactures, 7. Machines and transport equipment, 8.Miscellaneous manufactured goods. ${ }^{16}$ As mentioned above, due to data availability, the pass-through equation is estimated using monthly data over the period 1995:01-2013:12. ${ }^{17}$ Also, the sectoral ERPT is measured only for only eleven EA countries due to the lack of sufficient disaggregated data for Luxembourg. ${ }^{18}$

When examining the product composition of imports as shown in Figure 2, we observe that the importance of sectors varies across EA countries. On the one hand, Belgium,

\footnotetext{
${ }^{15}$ In some empirical studies, a higher level of disaggregation is used with 2- and 3-digit SITC product grouping (see e.g. Olivei, 2002; Yang, 2007; Auer and Schoenle, 2016, among others).

${ }^{16}$ To our best of knowledge, no data exist for category 9 (goods considered as n.e.s. or not elsewhere specified), which has a residual nature.

${ }^{17}$ For comparison purpose and robustness check, our next macro analysis in Section 4 is also conducted over the same period, i.e. since 1995:01 instead of 1990:01. This does not alter significantly our results of ERPT estimates at the aggregate level.

${ }^{18}$ For instance, in Campa et al. (2005) and Campa and Gonzàlez (2006), Belgium and Luxembourg are treated as a single country due to data availability reasons.
} 
Germany, and Ireland have the largest share of the manufacturing sectors (SITC 5, 6, 7, and 8) among our sample. For example, about $75 \%$ of imports are manufactured products in Germany. On the other hand, Greece, Portugal, and Spain correspond to the countries with the highest portion of mineral fuels (or energy) sector (SITC 3), which includes petroleum products. In Spain, more than $30 \%$ of imports are products stemming from the energy sector (SITC 3). In addition, within each country, the distribution of imports also varies widely across different product categories.

Table 2. Standard international trade classification

\begin{tabular}{ll}
\hline \hline SITC & Industry \\
\hline SITC 0 & Food and live animals \\
SITC 1 & Beverages and tobacco \\
SITC 0_1 & Food, Beverages and tobacco \\
SITC 2 & Crude materials, inedible, except fuels \\
SITC 3 & Mineral fuels, lubricants and related materials \\
SITC 33 & Petroleum, petroleum products and related materials \\
SITC 4 & Animal and vegetable oils, fats and waxes \\
SITC 2_4 & Raw Materials \\
SITC 5 & Chemicals and related products, n.e.s. \\
SITC 6 & Manufactured goods classified chiefly by material \\
SITC 7 & Machinery and transport equipment \\
SITC 8 & Miscellaneous manufactured articles \\
SITC 5_6_7_8 & Manufacturing \\
SITC 9 & Commodities and transactions not classified elsewhere in the SITC \\
\hline \hline
\end{tabular}

Source: United Nations Statistics Division.

Figure 2 shows that across all EA countries, the manufacturing sectors (SITC 5, 6, 7, and 8 ) account for the highest share of imports, followed by the mineral fuels sector. It is well known that partial pass-through is a common phenomenon, particularly among heterogeneous products (such as manufactured products), while more homogeneous products (such as raw materials) have a higher degree of exchange rate transmission (see e.g., Campa and Goldberg, 2002). ${ }^{19}$ Thus, the differences in trade composition observed in Figure 2 would have important implications, especially in explaining the significant differences in the aggregate import-price pass-through across our EA countries.

For purposes of illustration, we plot the correlation between the country-ERPT elasticities, as computed from Eqn.(5), and the share of different sectors (as percentage of

\footnotetext{
${ }^{19}$ As predicted by the law of one price, homogeneous goods must be sold at the same price when their prices are converted to a common currency, regardless of where these goods are sold.
} 
total imports). As reported in Figure 3, there is a negative relationship between the extent of pass-through and the share of manufacturing sectors (SITC 5, 6, 7 and 8) in total of imports (upper left subfigure). This implies that the larger share of differentiated goods (such as manufactured products) in total imports, the lower will be the degree of ERPT into import prices. This negative statistical correlation is more apparent with machinery and transport equipment sector (SITC 7). For a given economy, the larger portion of imported goods stemming from machinery and transport equipment sector, the less would be the extent passthrough (see upper right subfigure). For the homogeneous goods belonging to energy sector (SITC 3) or raw materials sector (SITC 2 and 4), the link is rather positive with the transmission of exchange rate changes. ${ }^{20}$ According to the bottom right subfigure in Figure 3 , the higher are the raw material imports, the more movements in exchange rates are transmitted to import prices. The same positive relationship is found with the energy sector (Mineral fuels, lubricants and related materials).

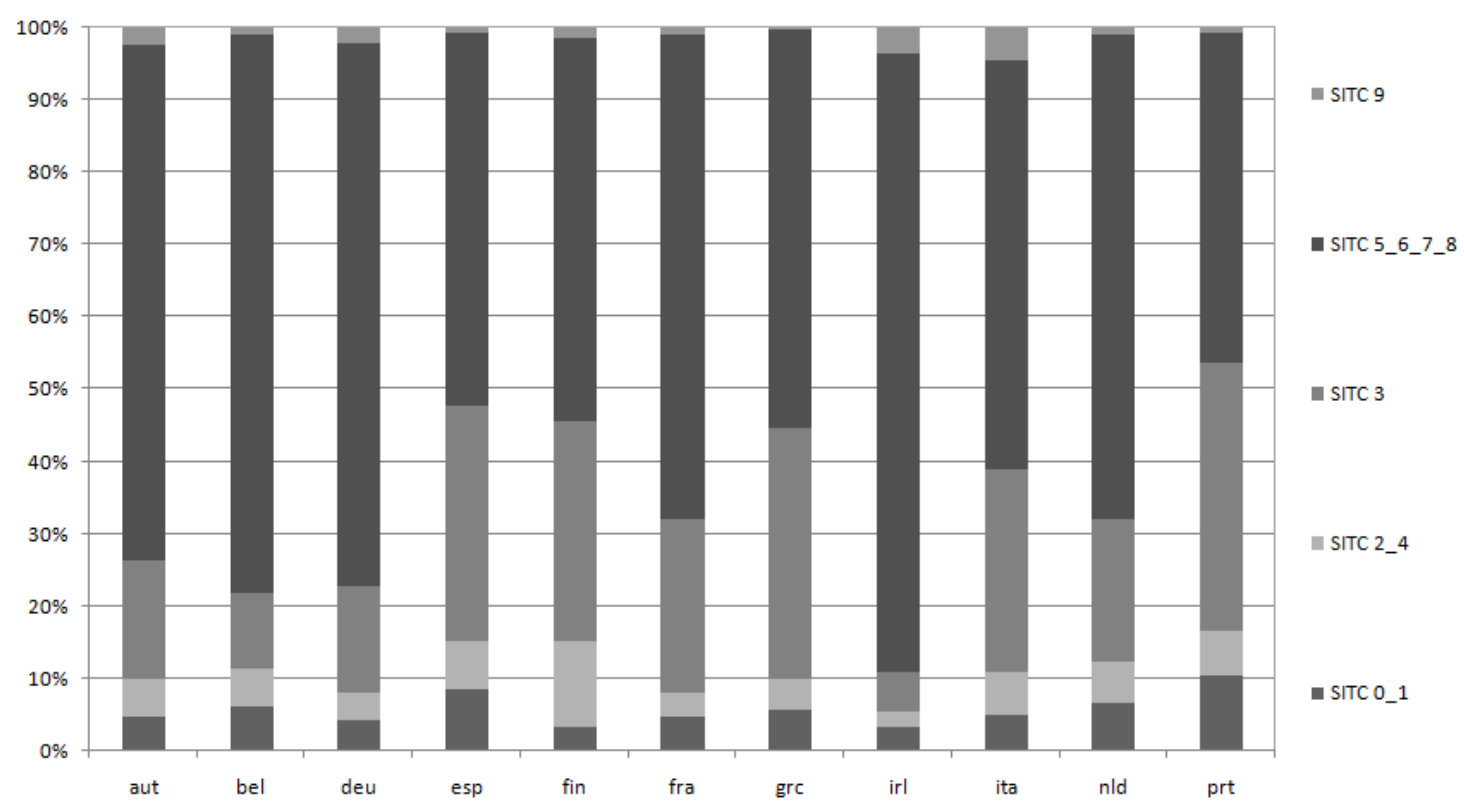

Figure 2. Share of imports per industry (average over 1995-2013)

Source: Eurostat COMEXT database

To provide insights on the Campa-Goldberg compositional-trade hypothesis, sectoral ERPT estimates obtained from Eqn.(6) using disaggregated import-price data are shown in Table $3 .{ }^{21}$ We focus on the short-run sectoral ERPT by calculating the coefficient $\beta_{1 i j}$ for each industry in each EA country. Table 3 reveals the higher variability of the extent of pass-

\footnotetext{
${ }^{20}$ Products belonging to energy and raw materials sectors can be viewed as being closer to classification as imported intermediate goods than food and manufacturing products.

${ }^{21}$ Stationarity check for disaggregate import prices data is also done within Elliott et al. (1996) unit-root test. First-differences variables are found to be stationary.
} 
through across and within EA countries; pass-through estimates are usually less than full across industries. The exceptions are mineral fuels (SITC 3) and raw materials (SITC 2 and 4) sectors where the hypothesis of complete ERPT $\left(\mathrm{H}_{0}: \beta_{1 i j}=1\right)$ is not rejected in most cases. Specifically, the hypothesis of null ERPT $\left(\mathrm{H}_{0}: \beta_{1 i j}=0\right)$ is not rejected for the Machinery and transport equipment sector (SITC 7) in most of the EA countries, except for Belgium, Ireland, and Spain. This behavior seems to be present usually in differentiated products (see e.g., Campa et al., 2005; Campa and Gonzàlez, 2006). At the other extreme, the mineral fuels sector (SITC 3) shows a full ERPT throughout our country sample; the null of $\mathrm{H}_{0}$ : $\beta_{1 i j}=1$ is not rejected in any case. The goods included in SITC 3 (such as oil) are examples of relatively homogeneous products. Consequently, our results confirm the conventional wisdom that the more a product is differentiated, the weaker the impact of the exchange rate will be on its import price.

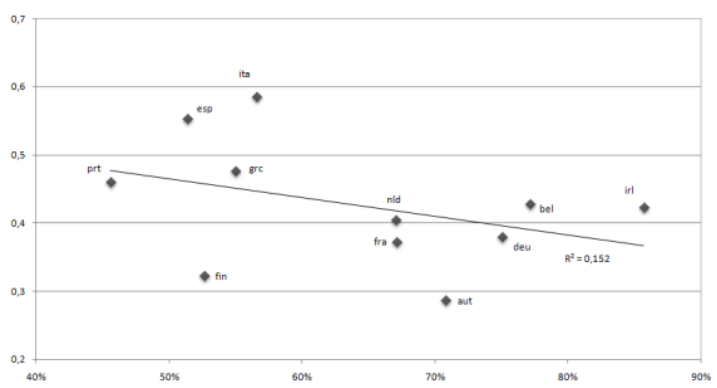

Share of manufacturing

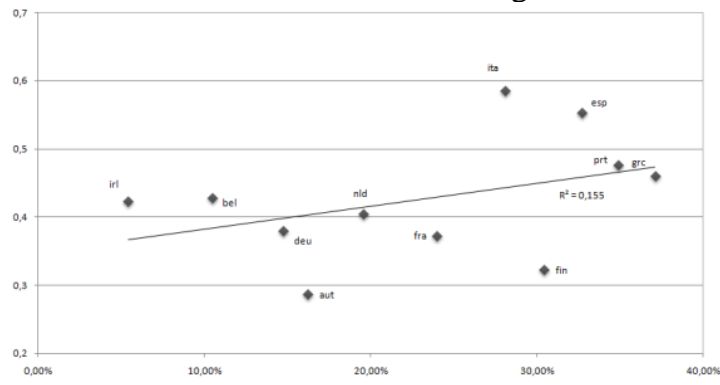

Share of energy

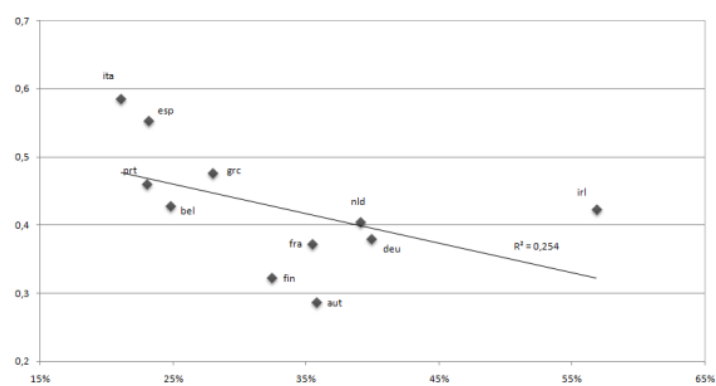

Share of machinery and transport

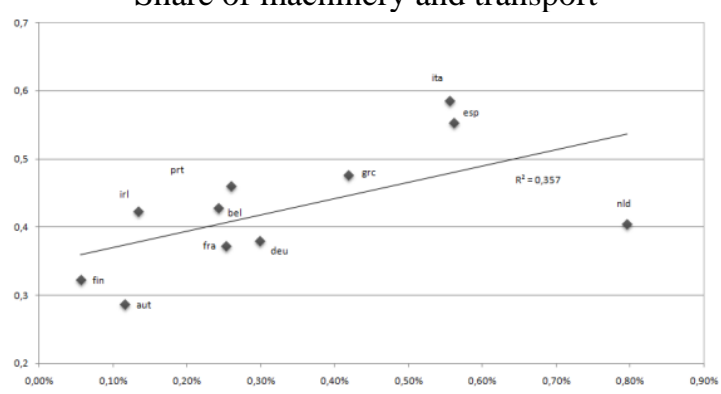

Share of raw materials

Figure 3. Correlation between ERPT and share of sector (\% of total imports)

Note: y-axis: ERPT to import prices estimated from individual estimations of Eqn.(5); $\mathrm{x}$-axis: share of sector in total imports (average over 1995-2013). 
Table 3: Sectoral ERPT estimates

\begin{tabular}{|c|c|c|c|c|c|c|c|c|c|c|c|}
\hline Industry & Austria & Belgium & Finland & France & Germany & Greece & Ireland & Italy & Netherlands & Portugal & Spain \\
\hline \multirow[t]{3}{*}{ SITC 0} & 0.418 & 0.349 & 0.381 & 0.476 & 0.232 & 0.075 & 0.492 & 0.641 & 0.413 & 0.012 & 0.381 \\
\hline & $(0.105)$ & (0.094) & $(0.000)$ & $(0.091)$ & $(0.018)$ & $(0.891)$ & $(0.065)$ & $(0.054)$ & $(0.230)$ & $(0.622)$ & $(0.047)$ \\
\hline & {$[0.024]$} & {$[0.002]$} & {$[0.000]$} & [0.063] & {$[0.000]$} & - & [0.057] & [0.282] & [0.088] & {$[0.000]$} & {$[0.001]$} \\
\hline \multirow[t]{3}{*}{ SITC 1} & 0.671 & 0.786 & 0.409 & -0.107 & -0.092 & 0.706 & 1.388 & -0.604 & -0.184 & 0.911 & 0.800 \\
\hline & $(0.385)$ & $(0.079)$ & $(0.177)$ & $(0.875)$ & $(0.196)$ & $(0.062)$ & $(0.627)$ & $(0.469)$ & $(0.717)$ & $(0.031)$ & $(0.111)$ \\
\hline & - & [0.633] & - & - & - & [0.437] & - & - & - & [0.833] & [0.690] \\
\hline \multirow[t]{3}{*}{ SITC 2} & 0.766 & 0.958 & 1.175 & 1.006 & 0.735 & 0.960 & 2.415 & 0.791 & 0.986 & 1.076 & 0.728 \\
\hline & $(0.079)$ & $(0.020)$ & $(0.021)$ & $(0.014)$ & $(0.203)$ & $(0.035)$ & $(0.165)$ & $(0.038)$ & $(0.101)$ & $(0.042)$ & $(0.001)$ \\
\hline & [0.591] & [0.919] & {$[0.732]$} & [0.787] & - & [0.931] & - & [0.583] & [0.981] & [0.886] & [0.227] \\
\hline \multirow[t]{3}{*}{ SITC 3} & 0.938 & 1.014 & 1.222 & 0.828 & 1.048 & 2.760 & 0.932 & 0.865 & 0.843 & 1.534 & 1.186 \\
\hline & $(0.029$ & $(0.012$ & $(0.030$ & $(0.007$ & $(0.002)$ & $(0.081)$ & $(0.011)$ & $(0.086)$ & $(0.041)$ & $(0.070)$ & $(0.035)$ \\
\hline & [0.884] & [0.973] & [0.694] & {$[0.573]$} & [0.890] & [0.266] & [0.853] & [0.788] & [0.703] & [0.529] & {$[0.741]$} \\
\hline \multirow[t]{3}{*}{ SITC 4} & 0.838 & 0.809 & 0.740 & 1.370 & 0.790 & 1.137 & 0.323 & 0.976 & 1.543 & 2.060 & 1.071 \\
\hline & $(0.009)$ & $(0.002)$ & $(0.336)$ & $(0.060)$ & $(0.151)$ & $(0.022)$ & $(0.103)$ & $(0.163)$ & $(0.091)$ & $(0.182)$ & $(0.235)$ \\
\hline & [0.613] & {$[0.456]$} & - & {$[0.612]$} & [0.703] & [0.783] & {$[0.001]$} & [0.973] & {$[0.551]$} & - & - \\
\hline \multirow[t]{3}{*}{ SITC 5} & 0.032 & 0.438 & 0.336 & -0.092 & 0.023 & -0.084 & -0.326 & 1.003 & 0.913 & -0.005 & 0.794 \\
\hline & $(0.506)$ & $(0.100)$ & $(0.132)$ & $(0.722)$ & $(0.746)$ & $(0.532)$ & $(0.470)$ & $(0.064)$ & $(0.001)$ & $(0.945)$ & $(0.017)$ \\
\hline & - & {$[0.035]$} & [0.003] & - & - & - & - & [0.995] & {$[0.760]$} & - & {$[0.535]$} \\
\hline \multirow[t]{3}{*}{ SITC 6} & 0.200 & 0.515 & 0.427 & 0.685 & 0.262 & 0.762 & -0.148 & 1.000 & 0.751 & 1.635 & 0.694 \\
\hline & $(0.110)$ & $(0.000)$ & $(0.037)$ & $(0.028)$ & $(0.001)$ & $(0.052)$ & $(0.727)$ & $(0.005)$ & $(0.085)$ & $(0.073)$ & $(0.062)$ \\
\hline & {$[0.000]$} & {$[0.000]$} & {$[0.005]$} & {$[0.312$} & {$[0.000]$} & {$[0.543]$} & - & [0.999] & {$[0.568]$} & [0.487] & [0.410] \\
\hline \multirow[t]{3}{*}{ SITC 7} & 0.005 & 0.119 & 0.281 & -0.039 & 0.157 & -0.366 & 1.159 & 0.746 & 0.782 & 0.438 & 0.438 \\
\hline & $(0.969)$ & $(0.049)$ & $(0.526)$ & $(0.601)$ & $(0.389)$ & $(0.646)$ & $(0.070)$ & $(0.097)$ & $(0.481)$ & $(0.395)$ & $(0.091)$ \\
\hline & - & [0.000] & - & {$[0.000]$} & - & [0.087] & [0.804] & [0.573] & - & - & [0.030] \\
\hline \multirow[t]{3}{*}{ SITC 8} & 0.174 & 0.233 & 0.609 & 0.518 & 0.283 & 1.074 & -0.013 & 0.453 & 0.986 & 0.833 & 0.694 \\
\hline & $(0.064)$ & $(0.001)$ & $(0.070)$ & $(0.035)$ & $(0.138)$ & $(0.055)$ & $(0.972)$ & $(0.002)$ & $(0.102)$ & $(0.099)$ & $(0.025)$ \\
\hline & [0.000] & {$[0.000]$} & [0.244] & [0.049] & {$[0.000]$} & [0.894] & - & [0.000] & [0.982] & [0.740] & {$[0.324]$} \\
\hline Country-ERPT & $\begin{array}{c}0.287 \\
(0.000) \\
\end{array}$ & $\begin{array}{c}0.428 \\
(0.000) \\
\end{array}$ & $\begin{array}{c}0.323 \\
(0.000) \\
\end{array}$ & $\begin{array}{c}0.372 \\
(0.000) \\
\end{array}$ & $\begin{array}{c}0.379 \\
(0.000) \\
\end{array}$ & $\begin{array}{c}0.476 \\
(0.000) \\
\end{array}$ & $\begin{array}{c}0.423 \\
(0.000) \\
\end{array}$ & $\begin{array}{c}0.586 \\
(0.000) \\
\end{array}$ & $\begin{array}{c}0.404 \\
(0.000) \\
\end{array}$ & $\begin{array}{c}0.460 \\
(0.000) \\
\end{array}$ & $\begin{array}{c}0.553 \\
(0.000) \\
\end{array}$ \\
\hline
\end{tabular}


Note: Sectoral ERPT estimations are based on Eqn.(6) using disaggregated import price data. Numbers in parentheses are $p$-values based on the null hypothesis of zero ERPT, et al., $\mathrm{H}_{0}: \beta_{1 i j}=0$. Numbers in square brackets are $p$-values, which corresponds to the null of full ERPT, i.e., $\mathrm{H}_{0}: \beta_{1 i j}=1$. The last row reports ERPT for each EA country obtained 
For a clearer picture of our sectoral pass-through estimates, we summarize results in a more tractable way by reporting summary statistics by industry and by country in Table 4 . The most striking result is that the ERPT is complete in the energy sector (SITC 3) for 100\% of our EA countries. Similarly, the responsiveness of import prices in crude materials (SITC 2 ) is found to be high, as $84 \%$ of our country sample shows full transmission for this kind of goods. Besides, a large portion of cases of zero ERPT is present in the beverages and tobacco (SITC 2) and machinery and transport equipment (SITC 7) sectors. The hypothesis of null ERPT is not rejected in 64\% of cases. Finally, the hypothesis of partial ERPT, i.e. where both the null and full ERPT hypotheses are rejected, is more frequent in the food (SITC 0) and miscellaneous manufactured goods (SITC 8) sectors.

Table 4. Summary of sectoral ERPT by industry and country

\begin{tabular}{lccc}
\hline \hline \multirow{2}{*}{ Industry } & \multicolumn{3}{c}{ Percentage of countries with } \\
\cline { 2 - 4 } & Full ERPT & Zero ERPT & Partial ERPT \\
\hline 0: Food and live animals & $9 \%$ & $27 \%$ & $64 \%$ \\
1: Beverages and tobacco & $36 \%$ & $64 \%$ & $0 \%$ \\
2: Crude materials & $82 \%$ & $18 \%$ & $0 \%$ \\
3: Mineral fuels & $100 \%$ & $0 \%$ & $0 \%$ \\
4: Oils, fats and waxes & $64 \%$ & $27 \%$ & $9 \%$ \\
5: Chemicals products & $27 \%$ & $55 \%$ & $18 \%$ \\
6: Manufactured goods & $55 \%$ & $9 \%$ & $36 \%$ \\
7: Machinery and transport equipment & $18 \%$ & $64 \%$ & $18 \%$ \\
8: Miscellaneous manufactured goods & $45 \%$ & $9 \%$ & $45 \%$ \\
\hline \hline
\end{tabular}

\begin{tabular}{lccc}
\hline \hline \multirow{2}{*}{ Country } & \multicolumn{3}{c}{ Percentage of industries with } \\
\cline { 2 - 4 } & Full ERPT & Zero ERPT & Partial ERPT \\
\hline Austria & $33 \%$ & $33 \%$ & $33 \%$ \\
Belgium & $44 \%$ & $0 \%$ & $56 \%$ \\
Finland & $44 \%$ & $33 \%$ & $33 \%$ \\
France & $44 \%$ & $33 \%$ & $22 \%$ \\
Germany & $44 \%$ & $22 \%$ & $33 \%$ \\
Greece & $67 \%$ & $33 \%$ & $0 \%$ \\
Ireland & $44 \%$ & $44 \%$ & $22 \%$ \\
Italy & $78 \%$ & $11 \%$ & $11 \%$ \\
Netherlands & $56 \%$ & $44 \%$ & $0 \%$ \\
Portugal & $56 \%$ & $44 \%$ & $0 \%$ \\
Spain & $67 \%$ & $11 \%$ & $22 \%$ \\
\hline \hline
\end{tabular}

Note: Full ERPT is the acceptance of $\mathrm{H}_{0}: \beta_{1 i j}=1$, zero ERPT is the acceptance of $\mathrm{H}_{0}: \beta_{1 i j}=0$ and partial ERPT is the rejection of both full and zero ERPT hypotheses. 
Overall, these results confirm the heterogeneity of the transmission of the exchange rate. We found a much higher degree of pass-through for more homogeneous goods and commodities, such as oil and raw materials, than for highly differentiated manufactured products, such as machinery and transport equipment. This outcome has an important implication for the evolution of the degree of ERPT over time. Campa and Goldberg (2005) have suggested that the shift in the composition of imports toward sectors with lower degrees of pass-through, namely manufactured differentiated goods, would explain the observed decline in ERPT across industrialized countries. Consequently, when the content of imports shifts from sectors with high pass-through rates into industries with lower rates, the country's overall import-price pass-through will decline. Conversely, a shift to higher pass-through products will raise the aggregate import price elasticity to exchange rate fluctuations for a given country. Besides, another interesting implication that should be underlined here. According to the level of product differentiation, "imported" inflation may impact differently the EA member states, depending on their relative different exposures to the rest of the world, i.e. extra-EA trade. For example, a Eurozone country with large imports from emerging market economies which generally export goods characterized by lower technological content - less differentiated products with less markup adjustment - would experience higher ERPT and inflationary pressures if the euro depreciates.

Next, we focus on the sectoral ERPT distribution by country as shown at the bottom of Table 4. Results indicate that Greece, Italy, and Spain have the largest portion of industries with full ERPT. This group of countries also has a small share of sectors with partial ERPT. For instance, the hypothesis of full ERPT is not rejected for $75 \%$ of Italian sectors, while in very few cases $(11 \%)$ the hypothesis of null ERPT is not rejected. By contrast, for the Austrian economy, we note a similar distribution of the degree of pass-through: the same percentage $(33 \%)$ is found for the respective hypotheses of full, null, and partial ERPT. As discussed earlier, the responsiveness of import prices at the industry level would explain the observed pass-through at the aggregate level for a given country. Consequently, it is worth noting that countries with a large share of industries with full ERPT coincide with economies with a higher overall rate of pass-through, which is the case for Greece, Italy, and Spain. Besides, differences in pass-through at the country level are related to the composition of country imports. The higher share of sectors with lower degrees of pass-through, such as the manufacturing sector, the lower the country-ERPT will be (and vice versa). Thus, the divergences in the product composition of imports, as shown in Figure 2, can account for a significant amount of the aggregate differences of import price pass-through across countries. 


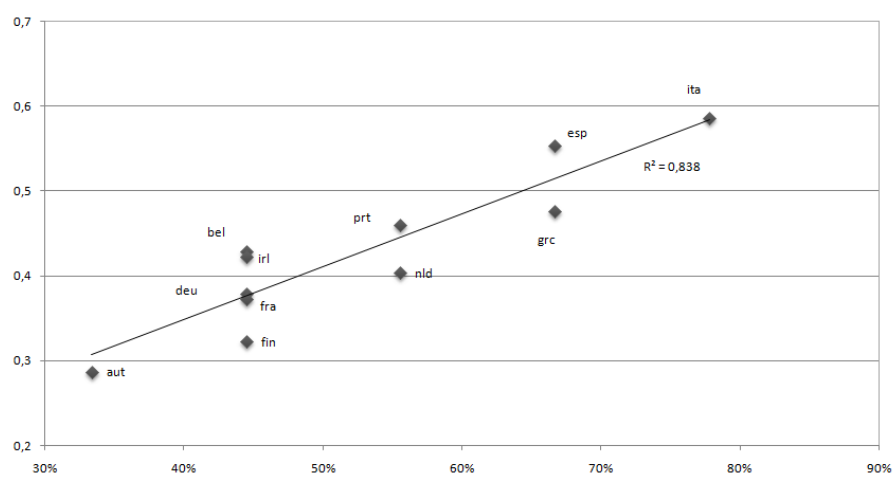

Sectors with full ERPT

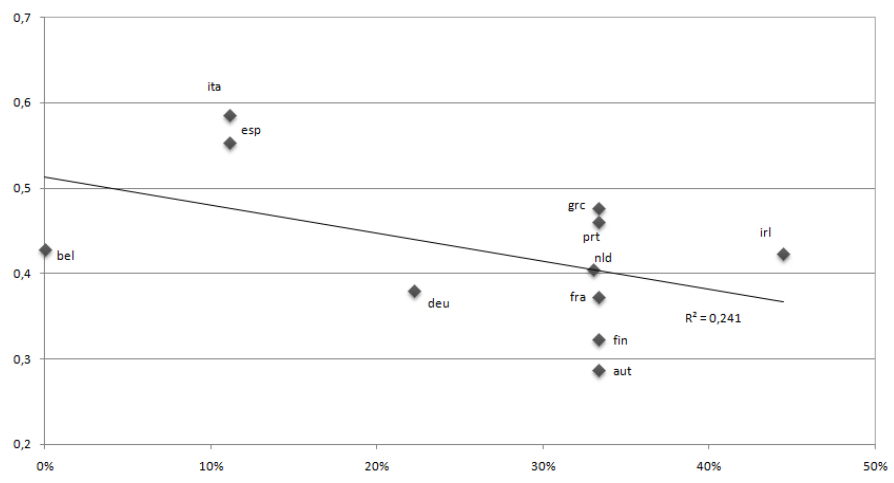

Sectors with zero ERPT

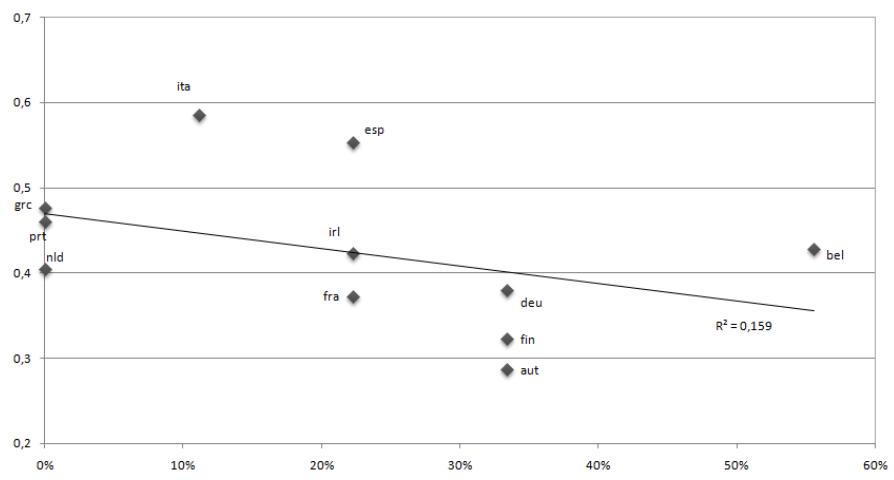

Sectors with partial ERPT

Figure 4. Correlation aggregate ERPT and percentage of industries with full, null and partial ERPT Note: y-axis: Country-ERPT to import prices obtained from individual estimations of Eqn.(5); x-axis: share of sectors with full, null, and partial ERPT.

Finally, to clarify the picture, we plot the correlation between the country-ERPT with the share of sectors with full, null, and partial ERPT, respectively. ${ }^{22}$ As expected, the first plot in Figure 4 reveals a positive correlation between the overall pass-through and the proportion of industries with full ERPT. The larger the share of sectors with complete transmission of exchange rate, the higher the response of the aggregate import prices will be. On the other

\footnotetext{
${ }^{22}$ The country-ERPT in each EA economy is calculated based on aggregate import prices which is reported in the last row of Table 3.
} 
hand, the aggregate country pass-through is negatively correlated to the percentage of sectors with null or partial ERPT. This result was expected since the larger the share of industries with null or full pass-through, the less movements in exchange rates are transmitted to import prices.

To sum up, it appears that the relative importance of different sectors in total import volumes considerably influences the overall observed pass-through rate of a given economy. Generally speaking, our results provide clear support for the Campa-Goldberg compositionaltrade hypothesis, i.e. the composition of country imports determines the aggregate response of import prices to exchange rate movements; consequently, possible differences in overall passthrough rates are due to an heterogeneous industry composition of trade across countries. In order to contribute to the debate on the prevalence of microeconomic factors vs. macroeconomic factors, in the next section we investigate for the potential role of some macroeconomic factors in explaining the ERPT.

\section{AGGEGATE RESULTS FROM A DYNAMIC PANEL DATA MODEL: A MACRO ANALYSIS OF THE PASS-THROUGH}

In the beginning, in order to provide some insight on the aggregate ERPT in the EA, we start by estimating our dynamic panel data benchmark specification as in Eqn.(5). As indicated earlier, we use two versions of the SYS-GMM estimator, SYS-GMM1 and SYSGMM2, which use respectively the collapsed two (or three)-period lags from all variables included in each estimation as the instruments sets. Results are shown in Table 5. Before commenting on these results, it is worth noting that our two SYS-GMM model specifications pass all the standard diagnostic tests, whose $p$-values are given in Table 5. In particular, there is no evidence of residual second-order autocorrelation, and the validity of the instruments is always confirmed by the Sargan-Hansen test. As explained earlier, the methodology developed by Arellano and Bover (1995) and Blundell and Bond (1998) assumes that there is no second order autocorrelation in the first-differenced errors.

To start with, the coefficients of the key variables are statistically significant with expected signs in our panel of 12 EA countries. Concerning pass-through estimates, the quarterly contemporaneous effect of the exchange rate movement, i.e. the short-run ERPT, is about $0.64 \%$ according to SYS-GMM1 and SYS-GMM2. Therefore, the transmission is relatively high but incomplete, since the null of full ERPT is rejected throughout the two estimations (see $p$-values in square brackets for $\mathrm{H}_{0}: \beta_{1}=1$ ). In the long-run, a $1 \%$ change in 
the rate of depreciation leads to $0.75 \%$ increase in the import-prices inflation in our EA sample. The long-run ERPT is slightly higher than in the short-run, but still incomplete.

Table 5. Panel ERPT estimates over 1990-2013

\begin{tabular}{|c|c|c|}
\hline & SYS-GMM1 & SYS-GMM2 \\
\hline \multirow[t]{2}{*}{$\Delta p_{i, t-1}^{m}$} & 0.159 & 0.112 \\
\hline & $(0.155)$ & $(0.000)$ \\
\hline \multirow[t]{3}{*}{$\Delta e_{i, t}$} & 0.634 & 0.646 \\
\hline & $(0.000)$ & $(0.000)$ \\
\hline & {$[0.000]$} & {$[0.000]$} \\
\hline \multirow[t]{2}{*}{$\Delta w_{i, t}^{*}$} & 0.911 & 0.880 \\
\hline & $(0.000)$ & $(0.000)$ \\
\hline \multirow[t]{2}{*}{$\operatorname{gap}_{i, t}$} & 0.249 & 0.209 \\
\hline & $(0.000)$ & $(0.000)$ \\
\hline \multirow[t]{3}{*}{$L R E R P T$} & 0.754 & 0.728 \\
\hline & $(0.000)$ & $(0.000)$ \\
\hline & {$[0.022]$} & {$[0.000]$} \\
\hline Observations & 211 & 211 \\
\hline \multirow[t]{2}{*}{$m 2$ test for autocorrelation } & 0.370 & 0.420 \\
\hline & $(0.713)$ & $(0.672)$ \\
\hline \multirow[t]{2}{*}{ Sargan-Hansen test } & 10.840 & 9.500 \\
\hline & $(0.287)$ & $(0.798)$ \\
\hline
\end{tabular}

Note: Estimations are based on Eqn.(5). Short-run ERPT corresponds to $\beta_{1}$ and long-run ERPT refers to $\beta_{1} /\left(1-\beta_{4}\right)$. The $p$-values in parentheses are based on the null hypothesis of zero ERPT, while $p$-values in square brackets correspond to the null of full ERPT. The $m 2$ test for autocorrelation has a null hypothesis of no autocorrelation, while the Sargan-Hansen test has the null hypothesis that the model and over-identifying conditions are correct specified with $p$-values reported in parentheses.

Besides, the estimated pass-through elasticities reported here are close to Campa and Gonzàlez (2006) with average elasticities of 0.62 and of 0.78 in the short and long-run, respectively. However, in the long-run, the authors find that the hypothesis of complete passthrough was not rejected for Finland, France, Greece, Italy, Portugal and Spain. Using dynamic panel data model for 11 industrialized countries, Bailliu and Fujii (2004) suggest an exchange-rate sensitivity of import prices close to $0.75 \%$ in the short-run and near complete $(0.91 \%)$ over the longer run. Overall, our results corroborate the conventional wisdom that the degree of ERPT is incomplete in the short-run. However, in the long-run, we found no evidence of complete pass-through. In their regression analysis, Choudhri and Hakura (2015) find that long-run import-price pass-through, for a set of advanced and emerging economies, is larger than the short-run pass-through but tends to be less than one. In all, for our $12 \mathrm{EA}$ countries, we conclude that partial ERPT is the best description for import price responsiveness in both the short-run and the long-run. 
In the next step, we test for the influence of some macroeconomics factors or common events (experienced by the EA countries) on the extent of pass-through, such as the inflation environment and the introduction of the euro. Other important factors are related to cycles and large exchange rate movements that have occurred several times in recent years across EA countries (see Figure 1). For instance, the large swings of the euro since 1999 might have affected the price stability in the monetary union. Moreover, the pass-through may have been higher until the end of the ERM crisis, an episode during which many European currencies experienced substantial depreciations. To check whether these events impacted the responsiveness of import prices, we construct the two following dummy variables:

- $\quad D^{e r m}$ which is equal to one during the ERM crisis (1992-1993) and zero otherwise; ${ }^{23}$

- $D^{\text {dep }}$ which is equal to one during the first 3years of the creation of the euro (19992001) and zero otherwise.

and we include them in our dynamic panel data model interacting with the exchange rate. Furthermore, to ensure the robustness of our findings with respect to the creation of the euro and the inflation environment as potential factors influencing the pass-through, the following two dummy variables are also created:

- $\quad D^{\text {euro }}$ which is equal to one since 1999 (the date of the inception of the euro) and zero before

- $\quad D^{\text {inf }}$ which is equal to one during low inflation periods and zero otherwise.

To identify low-inflation periods, we proceed as in Bailliu and Fujii (2004) by carrying out Bai and Perron's (2003) multiple break test on quarterly inflation series in each country. Then, when one break or more are identified, together with the visual inspection of inflation series, we are able to distinguish high from low inflation periods respectively. ${ }^{24}$ The results of Bai and Perron's (2003) multiple break test are summarized in Table 10 in Appendix B. Plots depicting the inflation series for each EA country are shown in Figure 5 in Appendix B, with vertical lines representing the dates at which the structural breaks were identified. According to these results, there is evidence of at least one break in all EA countries, and for some of them, two breaks are identified. It is also worth noting that for

\footnotetext{
${ }^{23}$ Since they joined the ERM mechanism at a later date, Austria, Finland, and Greece are excluded from the estimation when considering this dummy variable.

${ }^{24}$ To test whether pass-through has declined or not following a change in the inflation regime, Gagnon and Ihrig (2004) split their sample between high and low inflation period without testing for the presence of structural breaks in inflation series. In contrast, we follow Bailliu and Fujii (2004) by formally testing for structural breaks to identify low-inflation periods in our EA countries (see the econometric results for further details).
} 
several EA countries, periods of low inflation lie between the end of the ERM crisis (in 1994) and the launch of the euro (in 1999). It is clear that during the first years of the monetary union, there was an increase in inflation levels across our country sample.

We then reestimate Eqn.(5) by including separately our interactive dummy variables of interest $\left(D^{j} \times \Delta e_{i, t}\right)$ as follows:

$$
\begin{gathered}
\Delta p_{i, t}^{m}=\alpha_{i}+\mu_{t}+\beta_{1} \Delta e_{i, t}+\beta_{2} \Delta w_{i, t}^{*}+\beta_{3} g a p_{i, t}+\beta_{4} \Delta p_{i, t-1}^{m}+\beta_{5}\left(D^{j} \times \Delta e_{i, t}\right) \\
+\varepsilon_{i, t}
\end{gathered}
$$

where $D^{j}$ is the dummy variable interacted with the rate of exchange rate depreciation, $\Delta e_{i, t}$, chosen in the set $\left\{D^{e r m}, D^{\text {dep }}, D^{\text {euro }}, D^{\text {inf }}\right\}$ to capture specific events, such as the ERM crisis $\left(D^{e r m}\right)$ and the large depreciation of 1999-2001 $\left(D^{d e p}\right)$, or shifts in macroeconomic environment, such as the introduction of the euro $\left(D^{\text {euro }}\right)$ and the low-inflation regime $\left(D^{\text {inf }}\right)$. Note that in the empirical part of the paper, we estimate a separate panel regression for each dummy variable $D^{j}$, where $j=e r m$, dep, euro, inf. Then, to check whether our interactive terms $\left(D^{j} \times \Delta e_{i, t}\right)$ have an impact or not on the extent of pass-through, we compute the short-run and long-run ERPT as respectively $\left(\beta_{1}+\beta_{5}\right)$ and $\left(\beta_{1}+\beta_{5}\right) /\left(1-\beta_{4}\right)$. The use of interactive dummy variables to capture the effect of some specific events is a typical approach in the empirical literature. For instance, Bailliu and Fujii (2004) construct two policy dummy variables indicating shifts in the inflation environment in the 1980s and 1990s to check the impact of shifting towards low-inflation regime on ERPT. Their results indicate that the decline in pass-through over time was brought about by the inflation stabilization episodes that took place in the 1990s rather than in the 1980s. In a similar vein, to test whether the adoption of inflation targeting has had an impact or not on the degree of ERPT to consumer prices, Edwards (2006) creates a dummy variable equal to one at the time of the adoption of the inflation targeting, and zero otherwise. Using quarterly data for the period 1985-2005 for seven countries - two advanced and five emerging - that have adopted inflation targeting, the author found that pass-through has declined in most of the cases since the adoption of the inflation target regime.

The results of the impact of our macroeconomic factors are summarized in Table $6 .^{25}$ First, the ERM crisis over 1992-1993 seems not to have affected the sensitivity of import

\footnotetext{
${ }^{25}$ Similarly, when conducting the sectoral analysis of ERPT, it is possible to introduce interactive dummy variables in the individual regressions to test whether macro environments have statistically significant effects on ERPT. Doing so, we have obtained the same pattern, namely sharp-depreciation and low inflation periods impact significantly the extent of pass-through across EA countries. Results are not reported here to save space but available upon request.
} 
prices to exchange rate movements in the EA. Indeed, the interactive term $\left(D^{e r m} \times \Delta e_{i, t}\right)$ has a positive sign, meaning that ERPT is rising during this episode, but is not statistically significantly different from zero throughout SYS-GMM1 and SYS-GMM2 estimations. That is why, when computing the short-and long-run pass-through, as shown in Table 7, we find that estimates increase slightly in 1992-1993.

Table 6: Effects of the macroeconomic environment on ERPT

\begin{tabular}{|c|c|c|}
\hline \multirow{2}{*}{ Variables } & SYS-GMM1 & SYS-GMM2 \\
\hline & \multicolumn{2}{|c|}{ Effect of the ERM crisis } \\
\hline \multirow[t]{2}{*}{$\Delta e_{i, t}$} & 0.621 & 0.601 \\
\hline & $(0.000)$ & $(0.000)$ \\
\hline \multirow[t]{2}{*}{$D^{e r m} \times \Delta e_{i, t}$} & 0.065 & 0.069 \\
\hline & $(0.215)$ & $(0.289)$ \\
\hline
\end{tabular}

\begin{tabular}{lcc}
\hline & Effect of the euro depreciation (1999-2001) \\
\hline$\Delta e_{i, t}$ & 0.619 & 0.559 \\
& $(0.000)$ & $(0.000)$ \\
$D^{d e p} \times \Delta e_{i, t}$ & 0.075 & 0.118 \\
& $(0.046)$ & $(0.065)$ \\
\hline
\end{tabular}

\begin{tabular}{lcc}
\hline & \multicolumn{2}{c}{ Effect of the monetary union } \\
\hline$\Delta e_{i, t}$ & 0.618 & 0.649 \\
& $(0.000)$ & $(0.000)$ \\
$D^{\text {euro }} \times \Delta e_{i, t}$ & -0.027 & -0.037 \\
& $(0.167)$ & $(0.211)$ \\
\hline
\end{tabular}

\begin{tabular}{lcc}
\hline & \multicolumn{2}{c}{ Effect of low-inflation regime } \\
\hline$\Delta e_{i, t}$ & 0.677 & 0.665 \\
& $(0.000)$ & $(0.000)$ \\
$D^{i n f} \times \Delta e_{i, t}$ & -0.078 & -0.101 \\
& $(0.028)$ & $(0.024)$ \\
\hline \hline
\end{tabular}

Note: Estimations are based on Eqn.(7). Coefficients reported here are $\beta_{1}$ for $\Delta e_{i, t}$ and $\beta_{5}$ for the interactive terms $\left(D^{j} \times \Delta e_{i, t}\right)$. Numbers in parentheses are $p$-values.

Second, regarding the effect of the euro depreciation over 1999-2001, our results bring to light a significant increase in the responsiveness of import prices over this period. The interactive dummy variable $\left(D^{d e p} \times \Delta e_{i, t}\right)$ is positively significant according to GMM estimators (SYS-GMM1 and SYS-GMM2). Besides, according to SYS-GMM1 estimations shown in Table 7, the ERPT coefficient increased significantly from $0.62 \%$ to reach $0.70 \%$ in the short-run, while it changes from $0.70 \%$ to $0.78 \%$ in the long-run. This outcome is significant and has several important implications. On the one hand, our findings explain why 
the pass-through of the exchange rate has been a cause for concern for the ECB since the launch of the monetary union in 1999. The dramatic depreciation of the single currency represented a serious threat to price stability over the first 3 years of the euro. On the other hand, this would explain the failure in the literature to find a decline in ERPT since the formation of the EA in 1999. Despite the reduction of the share of imports affected by exchange rate fluctuations and the increase of the euro as an invoicing currency, we did not find that the ERPT has declined since the adoption of the single currency.

We believe that the significant increase in the extent of pass-through at the beginning of the creation of the euro has prevented the expected decline of the sensitivity of the import prices to exchange rate changes since 1999. After several years of depreciation, the euro has had a relatively stable appreciation since 2002. Consequently, to the extent that the euro has become a well-established currency, foreign firms would tend to choose it as the currency of denomination of their exports ( $L C P$, strategy), leading to a lesser degree of pass-through. This outcome was confirmed by De Bandt et al. (2008) who reported significant changes in ERPT behavior in the vicinity of the strengthening of the euro since 2002.

As a consequence, it is not surprising that the interactive terms included to capture the effect of introduction of the euro are found to be insignificant. As shown in Table 6, $\left(D^{\text {euro }} \times \Delta e_{i, t}\right)$ has an insignificant negative effect according to the SYS-GMM1 and SYSGMM2 estimation results. These findings may explain why the inception of the monetary union in 1999 did not entail a change in the magnitude of the ERPT in the EA.

Finally, we investigate whether the inflation environment influences or not the extent to which the exchange rate changes are transmitted into import prices. Table 6 shows that the low-inflation periods, as given by Bai and Perron's (2003) multiple break test, significantly dampen the effect of exchange rate changes on prices. The estimated coefficient for $\left(D^{\text {inf }} \times\right.$ $\left.\Delta e_{i, t}\right)$ is negative and statistically significant for the SYS-GMM1 and SYS-GMM2 estimations. The short-run pass-through rate is roughly $0.70 \%$ during high-inflation periods, and it is reduced to around $0.60 \%$ following a change towards a more stable inflation environment. Considering long-run elasticities, there was a fall from around $0.75 \%$ before the shift to around $0.66 \%$ in the low-inflation regime (see Table 7). These results are in line with Taylor's (2000) hypothesis, that is, the responsiveness of prices to exchange rate fluctuations tends to decline in a low and more stable inflation environment. Similarly, there was strong evidence in this direction in the empirical literature. This is especially true when comparing our estimates to those of previous studies. In their sample of 11 industrialized countries, Bailliu and Fujii (2004) found that the ERPT in the short-run declined from $0.86 \%$ to around $0.71 \%$ following a change in the inflation environment. Besides, recent studies, such as Lin 
and $\mathrm{Wu}$ (2012) and Hara et al. (2015), argued that the extent of pass-through is greater for countries that undergoing deflation, as is the case of Taiwan and Japan. When deflation occurs in the importing country, this would be harmful for profits due to weak domestic demand and falling prices. Thus, foreign firms tend to fully transmit the cost of exchange rate changes to prices of their product in the destination market, implying higher ERPT. For the case of Taiwan, Lin and $\mathrm{Wu}$ (2012) confirmed that a weak degree of pass-through is found in the low positive inflation environment. However, once the importing country is entering in a deflation regime, there is a rebound in ERPT which becomes inversely higher. As explained by the authors, it is crucial to clearly distinguish a deflation regime from a low-inflation regime, where a deflation environment is identified as a period of consumer-price changes less than 1\%. As a matter of fact, the sample period in our paper (1990:1-2013:4) does not cover a significant episode of deflation across the EA member states. The only exception was the second half of 2009 where the CPI inflation rate dramatically declined and became negative (see Figure 5 in Appendix B). ${ }^{26}$ This is mainly due to comparison effects with record high oil and food costs a year before, conjugated with weak economic activity induced by the financial crisis. Core inflation - which excludes energy, food, alcohol and tobacco - is still higher than headline rate, remaining into positive territory. ${ }^{27}$ At that time, there was a little concern that disinflation will worsen into deflation, and price growth has resumed later. ${ }^{28}$

Furthermore, while our paper focuses on the measurement of pass-through rates in a sample of Eurozone countries, our results would have some policy implications which are useful to understand the extent of ERPT in other regions in the world. As the responsiveness of import prices tends to decline in a low and more stable inflation environment, thus, countries that succeed to shift towards more credible and anti-inflationary monetary policy regimes are more likely to have low import-price pass-through. This is for example valid for some emerging Asian countries characterized by low inflation levels, such as Singapore and Taiwan (see e.g. Ca'zorzi et al., 2007). Similarly, since large and permanent currency fluctuations represent a serious threat to price stability, countries that manage to keep a stable nominal effective exchange rate, both in value and volatility terms, would experience a reduced degree of pass-through. Our findings reinforce the argument that the adoption of sounder policies may be an effective tool for reducing ERPT. This is especially true for countries with historically poor macroeconomic policies.

\footnotetext{
${ }^{26}$ June 2009 marked the first month of negative Eurozone inflation since the creation of the single currency in 1999.

${ }^{27}$ For example, the Taiwanese core CPI has exhibited a negative growth rate in the years that followed the Asian financial crisis.

${ }^{28}$ It should be noted that consumer prices developments over the last three years (2014-2016), has strengthened fears about deflationary risks. In January 2015 , prices plunged by 0.6 per cent, the lowest figure recorded since July 2009. The observed deflationary trend has become a serious concern for the ECB, with fears that the monetary union is drifting towards a Japanese-style deflation.
} 
Table 7. Short- and long-run ERPT over different macroeconomic environments

\begin{tabular}{lcc}
\hline \hline & Short-run ERPT & Long-run ERPT \\
\hline Outside the EMS crisis & 0.621 & 0.709 \\
& $(0.000)$ & $(0.000)$ \\
During the EMS crisis & {$[0.000]$} & {$[0.012]$} \\
& 0.686 & 0.783 \\
& $(0.000)$ & $(0.000)$ \\
\hline Outside the depreciation 1999-2001 & {$[0.000]$} & {$[0.002]$} \\
& 0.619 & 0.694 \\
During the depreciation 1999-2001 & $(0.000)$ & $(0.000)$ \\
& {$[0.000]$} & {$[0.000]$} \\
Pre-EA & 0.694 & 0.778 \\
& $(0.000)$ & $(0.000)$ \\
Post-EA & {$[0.000]$} & {$[0.000]$} \\
\hline \hline During low inflation & 0.618 & 0.883 \\
& $0.000)$ & $(0.000)$ \\
& {$[0.000]$} & {$[0.153]$} \\
& 0.591 & 0.844 \\
& $(0.000)$ & $(0.000)$ \\
& {$[0.000]$} & {$[0.023]$} \\
\hline During high inflation & 0.677 & 0.753 \\
& $(0.000)$ & $(0.000)$ \\
& {$[0.000]$} & {$[0.015]$} \\
& 0.598 & 0.666 \\
& $(0.000)$ & {$[0.000)$} \\
& {$[0.000]$} & $0.012]$ \\
\hline
\end{tabular}

Note: Estimations are based on Eqn.(7) using the SYS-GMM1 method. The ERPT elasticity in each macroeconomic environment is equal to $\left(\beta_{1}+\beta_{5}\right)$ in the short-run, and it corresponds to $\left(\beta_{1}+\beta_{5}\right) /\left(1-\beta_{4}\right)$ in the long-run. The $p$-values in parentheses are based on the null hypothesis of zero ERPT, while $p$-values in square brackets correspond to the null of full ERPT.

\section{CONCLUSIONS}

In this paper, we evaluate the first-stage pass-through, namely the responsiveness of import prices to the exchange rate changes, for a sample of EA countries. The aim of our study is to contribute to the debate on the prevalence of microeconomic factors vs. macroeconomic factors in determining the degree of ERPT. As a first step, we conduct a sectoral analysis of pass-through using disaggregated import prices data. Our results confirm the conventional 
wisdom that the more a product is differentiated, the weaker the impact of the exchange rate will be on its import price. We found a much higher degree of pass-through for more homogeneous goods and commodities, such as oil and raw materials, than for highly differentiated manufactured products, such as machinery and transport equipment. Our findings reveal that the product composition of imports is an important determinant of the aggregate ERPT of an economy. In this sense, cross-country differences in pass-through rates may be due to divergences in the product composition of imports. The higher share of imports from sectors with lower degrees of pass-through, such as the manufacturing sector, the lower the country-ERPT will be (and vice versa).

In the next step, we investigate for the influence of some macroeconomics factors or common events experienced by EA members, such as the formation of the euro, on the extent of pass-through. Using the System Generalized Method of Moments within a dynamic panel data model, our estimates indicate that decline of import-price sensitivity to the exchange rate is not significant since the introduction of the single currency. Our findings suggest instead that the weakness of the euro during the first three years of the monetary union significantly raised the extent of the ERPT. This outcome could explain why the sensitivity of import prices has not fallen since 1999. We also point out the significant role played by the inflation environment in influencing the ERPT. Specifically, we find that the responsiveness of import prices to exchange rate fluctuations tends to decline in a low and more stable inflation environment.

Our study contributes significantly to the debate regarding the prevalence of micro or macro factors in determining the extent of pass-through. The distinction between macro- and microeconomic factors is very important since these point to substantially different implications in policy terms. If pass-through is a macroeconomic phenomenon that is directly associated with monetary policy, such as inflation or exchange rate volatility, this implies that a given decline in pass-through may not necessarily be a permanent phenomenon because it may dissipate if monetary policy becomes more accommodating. In contrast, if ERPT is related to more structural factors, such as the industry composition of trade, the economic policy is less able to deal with the issue. Our findings support the view that the extent of passthrough has both macro- and microeconomic aspects that policymakers should take into account. 


\section{REFERENCES}

Arellano, M. and O. Bover (1995). Another look at the instrumental variable estimation of error-components models. Journal of Econometrics, 68, 29-51.

Auer, R.A., Mehrotra, A., (2014). Trade linkages and the globalisation of inflation in Asia and the Pacific. Journal of International Money and Finance, 49, 129-151.

Auer, R.A., Schoenle, R.S., (2016). Market structure and exchange rate pass-through. Journal of International Economics, 98, 60-77.

Bai, J. and P. Perron (2003). Computation and analysis of multiple structural change models. Journal of Applied Econometrics, 18 (1), 1-22.

Bailliu, J. and E. Fujii (2004). Exchange rate pass-through and the inflation environment in industrialized countries: An empirical investigation. Working Paper No. 2004-21, Bank of Canada.

Ben Cheikh, N., and C. Rault (2016). Recent estimates of exchange rate pass-through to import prices in the euro area. Review of World Economics, 152 (1), pp. 69-105.

Blundel, R. \& S., Bond (1998). Initial conditions and moment restrictions in dynamic panel data models. Journal of Econometrics, 87, 115-143.

Brun-Aguerre, R., A. Fuertes, and K. Phylaktis (2012). Exchange rate pass- through into import prices revisited: what drives it? Journal of International Money and Finance, $31(4), 818-844$.

Bussière, M. (2013). Exchange rate pass-through to trade prices: The role of nonlinearities and asymmetries. Oxford Bulletin of Economics and Statistics, 75 (5), 731-758.

Campa, J. and L. Goldberg (2002). Exchange rate pass-through into import prices: A macro or micro phenomenon? NBER Working Paper No. 8934.

Campa, J. and L. Goldberg (2005). Exchange rate pass-through into import prices. The Review of Economics and Statistics, 87 (4), 679.690.

Campa, J.M., L. Goldberg, and J.M. González-Mínguez (2005). Exchange rate pass-through to import prices in the euro area. National Bureau of Economic Research, Working Paper No.11632.

Campa, J.M. and J.M. Gonzàlez (2006). Difference in exchange rate pass-through in the euro area. European Economic Review, 50, 121.145.

Ca'Zorzi, M., E. Kahn, and M. Sánchez (2007). Exchange rate pass-through in emerging markets. ECB Working Papers Series 739.

Choudhri, E., \& Hakura, D. (2015). The exchange rate pass-through to import and export prices: The role of nominal rigidities and currency choice. Journal of International Money and Finance, 51(4), 1-25.

De Bandt, O., A. Banerjee, and T. Kozluk (2008). Measuring long run exchange rate passthrough., Economics: The Open-Access, Open-Assessment E-Journal, 2 (2008-6). 
Devereux, M. B., and J. Yetman. (2014). Globalisation, pass-through and the optimal policy response to exchange rates. Journal of International Money and Finance, 49, 104128.

Drine, I. and C. Rault, (2006). Testing for inflation convergence between the Euro Zone and its CEE partners. Applied Economics Letters, 13 (4), 235-240.

Edwards, S. (2006). The relationship between exchange rates and inflation targeting revisited. Working paper 12163, NBER.

Elliott, G., Rothemberg, T., \& Stock, J. (1996). Efficient tests for an autoregressive unit root. Econometrica, 64(4), 813-839.

Gagnon, J. and J. Ihrig (2004). Monetary policy and exchange rate pass-through. International Journal of Finance and Economics, 9 (4), 315.38.

Goldberg, L.S. and G. Tille (2008). Vehicle currency use in international trade. Journal of International Economics, 76, 177.192.

Hara, K., K. Hiraki and Y. Ichise (2015). Changing exchange rate pass-through in Japan: does it indicate changing pricing behavior? Bank of Japan Working Paper Series No.15 E4.

Ihrig, J. E., Marazzi, M., and A. Rothenberg (2006). Exchange rate pass-through in the G7 economies. Board of Governors of the Federal Reserve System International Finance Discussion Paper 851.

L'Horty, Y. and C. Rault (2004). Inflation, Minimum Wage and Other Wages: An Econometric Study of French Macroeconomic Data. Applied Economics 36 (4), 277290.

L'Horty Y. and C. Rault (2003). Why Is French Equilibrium Unemployment So High? An Estimation of the WS-PS Model. Journal of Applied Economics 6 (1).

L'Horty Y. and C. Rault (1999). Les causes du chômage en France: Une ré-estimation du modèle WS-PS. CSERC Working papers, ${ }^{\circ}$ 99-01.

Lin, P.-C. and C.-S. Wu (2011). Exchange rate pass-through in deflation: the case of Taiwan. International Review of Economics and Finance, 22, 101-111.

Marazzi, M., Sheets N., Vigfusson R., J. Faust, J. Gagnon, J. Marquez, R. Martin, T. Reeve, and J. Rogers (2005). Exchange rate pass-through to U.S. import prices: some new evidence. International Finance Discussion Paper No. 832, Board of Governors of the Federal Reserve System.

Nickell, S. (1981). Biases in dynamic models with fixed effects. Econometrica, 49, 14171426.

Olivei, G. P. (2002). Exchange rates and the prices of manufacturing products imported into the United States. New England Economic Review, First Quarter, 3.18.

Parent, A and C. Rault (2004). The Influences Affecting French Assets Abroad Prior to 1914. Journal of Economic History 64(2), 328-62. 
Pedroni, P. (2004). Panel cointegration: Asymptotic and finite sample properties of pooled time series tests with an application to the PPP hypothesis. Econometric Theory, 20, $597-625$.

Pesaran H. (2007). A simple panel unit root test in the presence of cross-section dependence. Journal of Applied Econometrics, 22, 265-312.

Roodman, D. (2006). How to do xtabond2: An introduction to "Difference" and "System" GMM in Stata. Center for Global development, Working Paper103.

Roodman, D., (2009). A note on the theme of too many instruments. Oxford Bulletin of Economics and Statistics, 71, 135-158.

Taylor, J. (2000). Low inflation, pass-through and the pricing power of firms. European Economic Review, 44, 1389.1408.

Westerlund, J., (2007). Testing for error correction in panel data. Oxford Bulletin of Economics and Statistics, Vol. 69 (6), 709-748.

Windmeijer, F. (2005). A finite sample correction for the variance of linear efficient twostep GMM estimators. Journal of Econometrics, 126, 25-51.

Yang, J. (2007). Is exchange rate pass-through symmetric? Evidence from us imports. Applied Economics, 39, 169.178. 


\section{APPENDIX A. PANEL UNIT ROOT AND COINTEGRATION TESTS}

Table 8. Pesaran's (2007) test for panel unit root

\begin{tabular}{lcc}
\hline \hline Variables & Intercept & Intercept \& trend \\
\hline$p_{i, t}^{m}$ & -0.301 & -1.952 \\
$\Delta p_{i, t}^{m}$ & -8.074 & -9.283 \\
$e_{i, t}$ & -0.783 & -0.940 \\
$\Delta e_{i, t}$ & -9.3162 & -10.541 \\
$w_{i, t}^{*}$ & -1.128 & -1.780 \\
$\Delta w_{i, t}^{*}$ & -7.770 & -11.068 \\
\hline \hline
\end{tabular}

Note: The empirical statistics can be compared with the critical value from Pesaran (2007), which are -2.15 for specification with an intercept and -2.65 for specification with intercept and linear time trend, at $5 \%$ level. Individual lag lengths are based on Akaike Information Criteria (AIC).

Table 9. Westerlund's (2007) Panel Cointegration Test

\begin{tabular}{lccc}
\hline \hline Statistic & Value & $p$-value & Robust $p$-value \\
\cline { 1 - 1 } Group-mean statistics & & & \\
\cline { 1 - 2 }$G_{\tau}$ & -1.682 & 0.675 & 0.400 \\
$G_{\alpha}$ & -6.704 & 0.634 & 0.146 \\
Panel statistics & & & \\
$P_{\tau}$ & -6.744 & 0.272 & 0.262 \\
$P_{\alpha}$ & -4.316 & 0.467 & 0.282 \\
\hline \hline
\end{tabular}

Note: $G_{\tau}$ and $G_{\alpha}$ are group mean statistics that test the null of no cointegration for the whole panel against the alternative of cointegration for some countries in the panel. $P_{\tau}$ and $P_{\alpha}$ are the panel statistics that test the null of no cointegration against the alternative of cointegration for the panel as a whole. Optimal lag and lead lengths are determined by Akaike Information Criterion (AIC). In the last column, we show the bootstrapped $p$-values that are robust against cross-sectional dependencies. The number of bootstraps is set to 800 . 
APPENDIX B. IDENTIFIED STRUCTURAL BREAKS IN THE CPI INFLATION SERIES

Table 10. Bai and Perron's (2003) multiple break test

\begin{tabular}{|c|c|c|c|c|c|c|c|c|c|c|c|c|}
\hline & Austria & Belgium & Finland & France & Germany & Greece & Ireland & Italy & Luxembourg & Netherlands & Portugal & Spain \\
\hline \multicolumn{13}{|l|}{$\operatorname{Sup}_{F}(m)$} \\
\hline 1 & 89.058 & 34.568 & 81.443 & 58.156 & 123.119 & 287.721 & 48.582 & 358.811 & 40.505 & 43.362 & 261.028 & 143.549 \\
\hline 2 & 65.730 & 29.489 & 44.096 & 38.643 & 65.005 & 443.772 & 45.076 & 315.335 & 69.427 & 39.713 & 147.645 & 88.477 \\
\hline 3 & 42.762 & 20.962 & 36.113 & 61.399 & 49.112 & 303.005 & 44.852 & 221.939 & 51.236 & 47.108 & 98.309 & 114.396 \\
\hline \multicolumn{13}{|c|}{$\operatorname{Sup}_{F}(m \mid m-1)$} \\
\hline$(1 \mid 0)$ & 89.058 & 34.568 & 81.443 & 58.156 & 123.119 & 287.721 & 48.582 & 358.811 & 40.505 & 43.362 & 261.028 & 143.549 \\
\hline \multicolumn{13}{|c|}{ No. of breaks selected } \\
\hline Sequential & 2 & 2 & 2 & 2 & 1 & 2 & 3 & 2 & 2 & 3 & 1 & 1 \\
\hline \multirow[t]{3}{*}{ Break dates } & 1995:06 & 1994:09 & 1992:12 & 1992:12 & 1994:06 & 1995:01 & 1992:09 & 1992:02 & 1994:02 & 1994:12 & 1994:06 & 1990:01 \\
\hline & 2000:01 & 1999:11 & 1999:10 & 2000:05 & & 1999:04 & 1999:12 & 1996:08 & 1999:11 & 2000:12 & & \\
\hline & & & & & & & 2003:04 & & & 2002:12 & & \\
\hline
\end{tabular}

Note: The $\operatorname{Sup}_{F}(m)$ statistics tests for the null hypothesis of no structural break against $m(m=1,2,3)$ breaks. The $\operatorname{Sup}(m \mid m-1)$ statistics for the null hypothesis of $(m-1)$ structural breaks against $m(m=1,2,3)$ structural breaks. Last row provided suggested break dates based on the results of these sequential tests. 


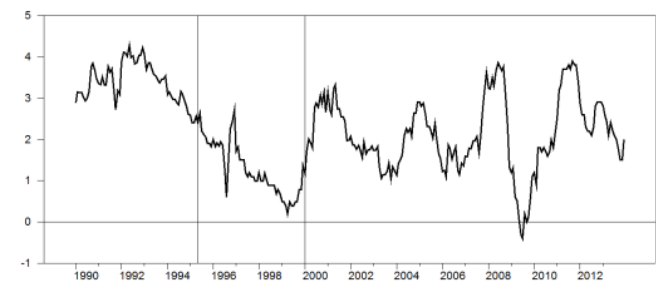

Austria

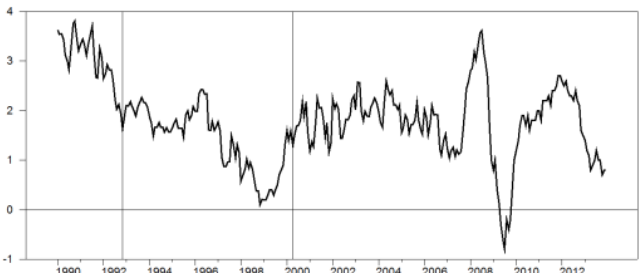

France

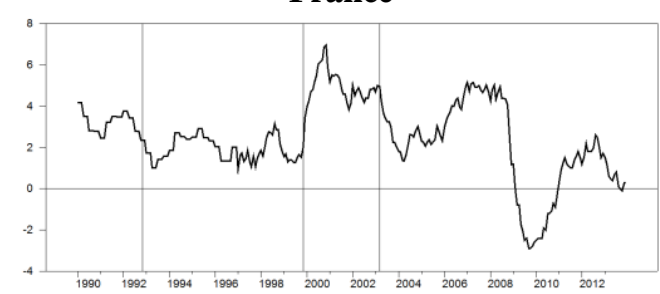

Ireland

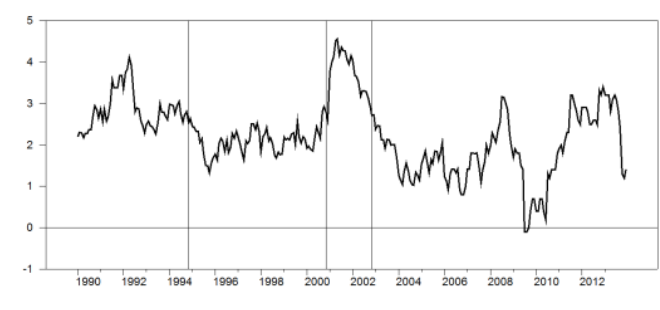

Netherlands

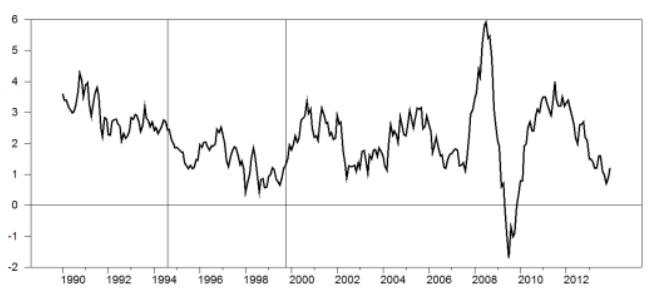

Belgium

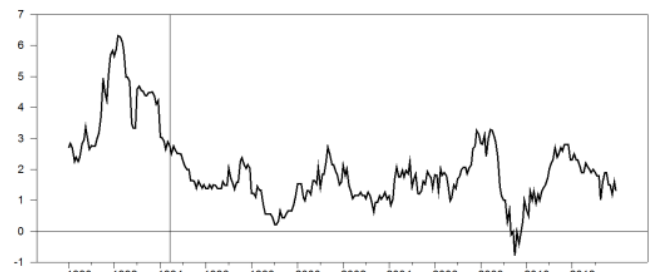

Germany

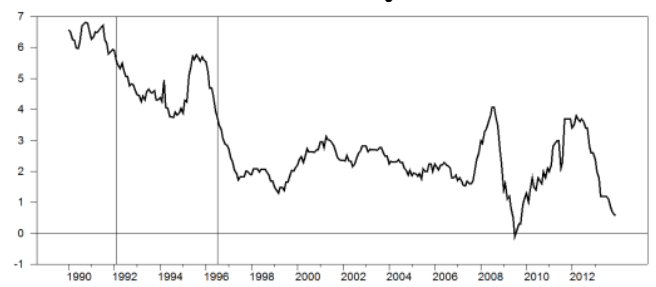

Italy

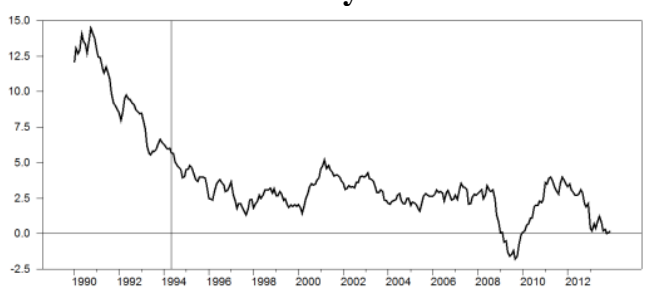

Portugal

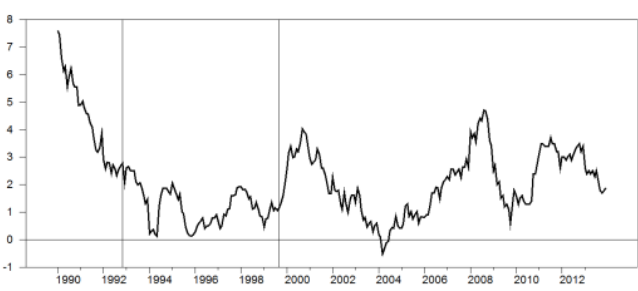

Finland

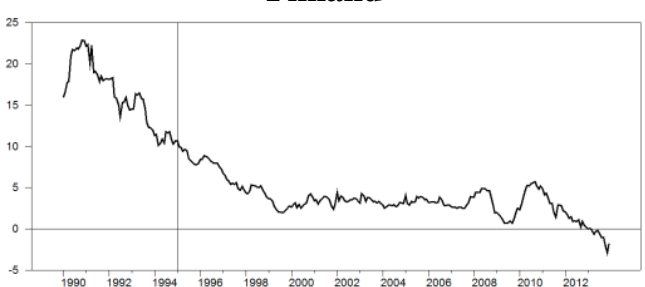

Greece

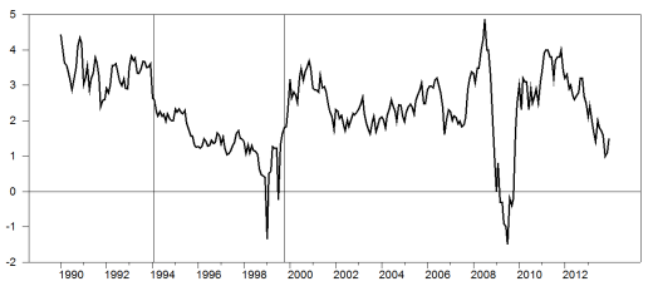

Luxembourg

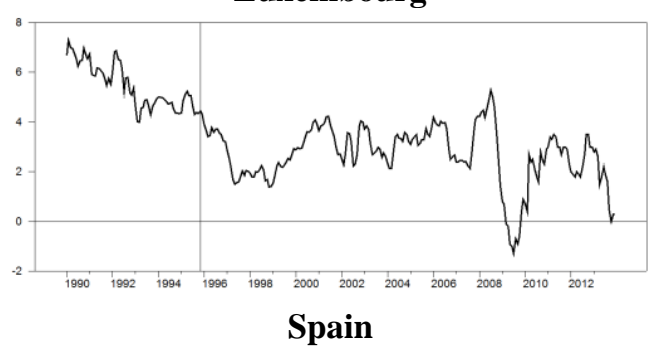

Figure 5. Structural breaks in inflation series 